Discussion Paper No. 685

\title{
HAS DEMOCRATIZATION REDUCED INFANT MORTALITY IN SUB-SAHARAN AFRICA? EVIDENCE FROM MICRO DATA
}

Masayuki Kudamatsu

The Ninth ISER-Moriguchi Prize (2007)

Awarded Paper

March 2007

The Institute of Social and Economic Research Osaka University

6-1 Mihogaoka, Ibaraki, Osaka 567-0047, Japan 


\title{
Has Democratization Reduced Infant Mortality in Sub-Saharan Africa? Evidence from Micro Data*
}

\author{
Masayuki Kudamatsu ${ }^{\dagger}$ \\ Department of Economics and STICERD \\ London School of Economics and Political Science
}

December 15, 2006

\begin{abstract}
Does democracy help babies survive in sub-Saharan Africa? By using retrospective fertility surveys conducted in 28 African countries, I compare the survival of infants born to the same mother before and after democratization to identify the effect of democracy. In measuring democracy, I adopt a theoretically motivated definition of democracy: universal suffrage and contested elections for executive office. I find that infant mortality falls by 1.8 percentage points, 18 percent of the sample mean, after democratization. The size of the reduction is larger for babies born to mothers from disadvantaged groups. I also find that the replacement of a chief executive by democratization is the driving force behind these results. Additional evidence suggests that improvements in public health service delivery, not an increase in affluence, are the key mechanism in which democratization has reduced infant mortality.
\end{abstract}

*I thank Maitreesh Ghatak and Tim Besley for their continuous support and valuable comments, and Robin Burgess and Oriana Bandiera for helpful comments at various stages of this research. I am also grateful to Fernando Aragon, Yutaka Arimoto, Dave Donaldson, Ray Fisman, Hiro Ishise, Hisaki Kono, Rocco Macchiavello, Torsten Persson, Steve Pischke, Jim Snyder, and seminar participants at the 4th Development Economics PhD Seminar held in University of Namur, at University of Warwick, and at London School of Economics for helpful suggestions and discussions. Sylvia Meek kindly guided me through the public health literature. Data appendices to this paper are available on my website: http://personal.lse.ac.uk/kudamats/research.htm

${ }^{\dagger}$ Email address: m.kudamatsu@lse.ac.uk 


\section{Introduction}

Does democracy promote development? This question has long attracted attention from many social scientists. Despite a large number of empirical studies on this subject, evidence remains inconclusive because it is difficult to establish causality running from democracy to development: democracy is likely to be endogenous to socio-economic factors that also affect development (Lipset 1959). The empirical challenge is to disentangle the effect of democracy from other confounding factors. This paper revisits this question in the context of human development in sub-Saharan Africa. Specifically, I investigate whether democratization sweeping the region in the 1990s has reduced infant mortality, by using a cross-country micro panel dataset covering 28 countries in the region.

How to confront underdevelopment in sub-Saharan Africa is one of the most important questions in economics today. Economists, however, have so far ignored one important change that the world's poorest region recently experienced: a wave of democratization in the 1990s. By the end of 2000, among the 48 countries in sub-Saharan Africa "[o]nly Congo-Kinshasa, Eritrea, Rwanda, Somalia, Swaziland, and Uganda held no multiparty elections whatsoever." ${ }^{1}$ Much has been discussed, by political scientists and Africanists, on what caused democratization in Africa and whether new democracies in the region will be consolidated. ${ }^{2}$ Very few, however, pay attention to how this political change has affected the lives of people in sub-Saharan Africa. ${ }^{3}$ Perhaps because of this, the pessimism on the quality of African government is deeply entrenched in any debate on African underdevelopment. The longstanding question of whether democracy promotes development, therefore, gains additional importance in sub-Saharan Africa.

As a measure of development, this paper focuses on infant mortality, defined as death within the first year of life. The survival of infants remains a huge concern in sub-Saharan Africa today. Figure 1 plots infant mortal-

\footnotetext{
${ }^{1}$ Van de Walle (2002), p.67. See also Bratton (1998) and Lindberg (2003). Rwanda then held multiparty elections in 2003, and Congo-Kinshasa in 2006. Uganda has been holding multi-candidate elections since 1996.

${ }^{2}$ One exogenous factor that contributes to democratization in Africa in the 1990s is the end of the Cold War. The news of the collapse of communist dictatorships encouraged Africans to protest against non-democratic regimes. Western donor countries became reluctant to provide development assistance to African countries unless democracy was introduced. These changes often forced African dictators to accept the introduction of multiparty elections.

${ }^{3}$ An exception to this is Stasavage (2005), who looks at whether democratization in Africa has improved primary school attendance.
} 
ity rates per 1,000 live births by developing region over time. Sub-Saharan Africa has been lagging behind other regions in reducing infant mortality, since 1980 in particular, with more than one in ten babies still dying before turning one year old in 2000. In addition, focusing on infant mortality has a methodological advantage: unlike other socio-economic outcomes such as personal income, the data at the individual level across many countries over a long period of time is available from the retrospective fertility survey component of the Demographic and Health Surveys (DHS), conducted in 28 African countries after the mid-1990s. In these surveys, women of childbearing age report when their children were born and whether, and when (if applicable), they died. As surveyed women in Africa give birth to four children on average during their lifetime, I observe a sizable number of mothers having babies both before and after democratization in the 1990s. This characteristics of the data allows me to identify the effect of democratization by exploiting within-mother variation in the survival of babies, instead of cross-country or within-country variation. As a result, the estimated effect of democratization on infant mortality is robust to a possibility that changes in the composition of the population over time (e.g. overall education level) drive both democratization and changes in infant mortality with no direct relationship between the two.

The DHS surveys also provide information on socio-economic characteristics of interviewed mothers, including their educational attainment and ethnicity. Using this information, I check if the effect of democracy is larger for babies born to disadvantaged groups of mothers such as those uneducated or those whose ethnicity is different from the former dictator's. The fundamental idea of democracy is to give voice to every citizen in a country whereas typically only a few people can influence policy-making under dictatorship. The effect of democratization will therefore be larger for groups of people who are otherwise excluded from political process. The use of individual-level data allows me to see if this argument holds in reality.

Last but not least, any discussion regarding democracy faces a thorny issue of what constitutes democracy. In this paper, I define democracy as a political institution satisfying the following two conditions: (1) the chief executive of the government has been elected in multiparty elections with universal suffrage, without subsequently banning opposition parties and (2) the first multiparty election brings in a new chief executive to office. Political economy models predict that the combination of contested elections and universal suffrage - features of democracy underlying the first condition - will provide an incentive for the government to implement public health interventions to combat infant mortality. Several additional arguments sug- 
gest that contested elections and universal suffrage do not make a difference in policy-making unless the second condition is also satisfied. To identify the year of democratization defined this way, I originally collect information on these requirements for a country to be democratic. I check how results differ when I drop the second requirement in the definition above or rely on widely-used democracy indicators to define democracy instead. I also check whether leadership without democratization reduces infant mortality. By doing so, I try to make some progress in our understanding of what features of democracy, and what combination of them, contribute to development.

My findings are as follows. Democratization has reduced infant mortality in sub-Saharan Africa by 1.8 percentage point, roughly equivalent to what the region as a whole has achieved over the past two decades (see Figure 1). The effect of democratization emerges immediately and becomes larger over time. A sizable portion of this reduction comes from a fall in neonatal mortality, the number of deaths within the first month of life. The effects of democratization on both infant and neonatal mortality are larger for babies born to uneducated mothers and mothers who do not share their ethnicity with the dictator who ruled the country until democratization. There is no such reduction in infant mortality in countries where the dictator holds multiparty elections and stays in power by winning them. When the year of democratization is identified from widely-used democracy indicators, estimation results suggest that such measures of democracy may be subject to measurement error.

Additional evidence suggests that maternal health care provision to uneducated mothers has expanded since democratization, consistent with the finding that democratization has reduced neonatal mortality, especially for babies born to uneducated mothers. The breastfeeding practice has spread after democratization, which can explain the immediate effect of democratization. Access to better sanitation facilities has also expanded, consistent with the growing effect of democratization over time. On the other hand, there is no evidence for an increase in affluence after democratization. Consequently, the key mechanism in which democratization has reduced infant mortality in sub-Saharan Africa is likely to be improvements in public health service delivery, not in overall living standards.

This paper contributes to the large empirical literature that tries to identify the effect of democracy on development or other socio-economic outcomes. I am not aware of studies using micro panel data to estimate the effect of democracy. Most studies focus on economic growth as an outcome variable. As the source of identification, early studies reviewed in Przeworski and Limongi (1993) hinge on cross-country variation while re- 
cent studies rely on within-country variation (Papaioannou and Siourounis 2004 and Rodrik and Wacziarg 2005). Others look at the effect of democracy on manufacturing wages (Rodrik 1999), child immunization (Gauri and Khaleghian 2002), socio-economic policies (Mulligan, Gil, and Sala-i-Martin 2004), and life expectancy at birth (Besley and Kudamatsu 2006). Ross (2006) studies the effect of democracy on infant mortality at the country level, finding no association between the two. This finding may, however, be subject to confounding factors at the country level.

As an attempt to disaggregate a blunt concept of democracy in the estimation of its effect, this paper is also related to works summarized in Persson and Tabellini (2006). Finally, this study contributes to recent debates on how to improve public service delivery in poor countries (e.g. World Bank 2003; Banerjee and Duflo 2006; Chaudhury, Hammer, Kremer, Muralidharan, and Rogers 2006).

The rest of the paper is organized as follows. The next section discusses how I measure democracy in sub-Saharan Africa and describes the individual-level data on infant mortality. Section 3 describes empirical method, reports main results, checks their robustness, and investigates what type of democracy matters for infant mortality. Section 4 provides evidence for possible pathways from democratization to the reduction of infant mortality. Section 5 concludes.

\section{Background and Data}

To estimate the effect of democratization on infant mortality at the individual level, we need to decide how to measure democracy and to obtain micro data on the survival of babies. In this section, I first discuss how I measure democracy and, based on this measure, show how democracy has evolved in African countries in the sample. Then I describe the Demographic and Health Surveys from which I obtain micro data on infant mortality.

\subsection{Measuring Democracy in Africa}

Democracy is a multi-faceted political institution. Some features of democracy may affect a certain outcome while other features may not. To identify the effect of democracy, therefore, we need to choose the appropriate definition of democracy depending on what outcome we study. In this paper, I define democracy as a political system in which (1) the chief executive of the government has been elected in multiparty elections with universal suffrage without subsequently banning opposition parties and (2) a new chief 
executive assumed office after the first multiparty elections. Below I explain theoretical motivations behind these two conditions for democracy.

The key concepts underlying the first condition are contested elections and universal suffrage. The political economy literature provides at least two reasons for which public health interventions to reduce infant mortality will be implemented after the introduction of contested elections with universal suffrage. First, the median voter theorem, combined with the assumption that public health interventions are the policies the majority of all citizens prefer, predicts that contested elections with universal suffrage make politicians propose public health policies to assume office. Under universal suffrage, candidates proposing policies favored by the majority of the population will win elections. ${ }^{4}$ Second, under the assumption that public health interventions are the provision of public goods, the model of distributive politics indicates that implementing public health interventions is less costly for politicians to win the majority of votes than distributing private goods to each voter, because under universal suffrage politicians need to appease a large number of people to win elections. ${ }^{5}$ These two arguments suggest that contested elections and universal suffrage are complements. If suffrage is limited to a certain segment of the population, contested elections alone do not ensure that politicians propose policies favored by the majority of the population or provide public goods to appease a large number of people, because they can still win the elections without doing so. Likewise, universal suffrage alone does not lead to the implementation of these policies because politicians will stay in office anyway by "winning" non-contested elections.

There are reasons to believe that public health policy to combat infant mortality was one of the policies the majority of the population prefer in sub-Sahara African countries in the early 1990s, when democratization took place (see below). In 1990, only $33 \%$ of the population had access to improved sanitation facilities in sub-Saharan Africa (World Development Indicators 2005). Only $40 \%$ of births in the region in 1990 were attended by skilled health personnel (Table 2 in UNICEF 2006). ${ }^{6}$ These figures suggest that the provision of sanitation facilities and skilled child delivery care would benefit the majority of the population in the region in the early 1990s.

Public health interventions to reduce infant mortality also have a public good component in sub-Saharan Africa because a large number of child

\footnotetext{
${ }^{4}$ Acemoglu and Robinson (2000) develop a model of democratization based on this idea.

${ }^{5}$ See Bueno de Mesquita, Morrow, Siverson, and Smith (2002) and Lizzeri and Persico (2004) for this line of arguments.

${ }^{6}$ See section 4 for how these two public health interventions affect infant mortality.
} 
deaths in the region are caused by infectious diseases. According to estimates provided by Murray and Lopez (1996, Appendix Table 6f), the following four infectious diseases together account for about 65 percent of 4.03 million deaths of children aged under 5 years in sub-Saharan Africa in 1990: diarrhea (20\%), lower respiratory infections (e.g. pneumonia) (18\%), malaria (15\%), and measles $(12 \%) .{ }^{7}$ Providing preventive measures and treatments against these diseases, therefore, benefits all infants living in the same area. ${ }^{8}$

The argument has so far indicated that politicians need to be elected in contested elections with universal suffrage so that democratization leads to a reduction in infant mortality. Further considerations refine this condition in three ways. First, contested elections must be multiparty elections. It may be difficult for opposition candidates without the support of political parties to defeat the incumbent, undermining the incentive for the government to adopt policies favored by the majority or to provide public goods. This is particularly important in the parliamentary system of government. Second, the political agency model (Barro 1973; Ferejohn 1986) suggests that, if the chief executive elected in multiparty elections bans opposition parties, he or she loses an incentive to implement policies favoured by the majority of citizens. Therefore, opposition parties need to be legal to exist after multiparty elections are held. Finally, the political office that is filled via multiparty elections must be an effective one in policy-making. Otherwise multiparty elections do not bring about policy change. The literature on African politics indicates that such political office is the chief executive. ${ }^{9}$

The second condition for a country to be democratic - the replacement of a chief executive - is an equilibrium outcome rather than the rule of the game. There are, however, several reasons to believe that leadership turnover is necessary for contested elections with universal suffrage to have any bite.

If a dictator decides to introduce multiparty elections in which he intends to run as a candidate and actually wins, he does so because he knows he can win. This may be due to his popularity relative to potential opposition

\footnotetext{
${ }^{7}$ Estimates for infant death (i.e. death during the first year of life) are not available. In 1990, HIV accounts for only 1.5 percent of child deaths in sub-Saharan Africa.

${ }^{8}$ Mani and Mukand (2006) offer another possible explanation for why health policies may change after democratization. Outcomes caused by health policies may be easier for voters to observe than, say, economic growth at the country level. This observability of health outcomes for voters creates an incentive for policy-makers who seek re-election to prioritize health issues over others. This effect does not emerge under non-democratic policy-making.

${ }^{9}$ For example, van de Walle (2003, p.310) notes that "power is highly centralized around the president".
} 
candidates or due to his capability of rigging the votes. As a result, he does not need to change his policy to win multiparty elections. (See Przeworski et al. 2000, pp. 23-8, for a similar argument.)

The second reason is that the identity of political leaders matters for policy-making. ${ }^{10}$ Democratization may bring about change in government policy only if it replaces policy-makers with those whose policy preference is different from their predecessor.

Yet another reason can be given based on Acemoglu and Robinson (2006). They argue that democratization does not lead to change in economic institutions if the elite can intensify their influence on policy outcomes through what they call de facto political power, such as lobbying. This argument may apply to health policies as well. Change in political leadership after democratization may increase the cost of lobbying for the elite as they need to cultivate personal connections with new political leaders from scratch. As a result, the cost of intensifying political influences outweighs its benefit, allowing democratization to bring policy change.

Whether or not these arguments hold true is, however, an empirical question. In section 3.4, I investigate whether the replacement of a chief executive is necessary for democratization to have an impact on infant mortality.

As none of the existing democracy datasets collect all of the requirements for democracy discussed above, I need to originally create the measurement of democracy. ${ }^{11}$

For each of the 28 sub-Sahara African countries for which the DHS surveys were conducted since 1996 (see section 2.2 below) and for the beginning of each year since independence or 1950, I collect information on who the chief executive of the government is, whether the chief executive in office (or national legislature if a country adopted the parliamentary form of gov-

\footnotetext{
${ }^{10}$ There is a growing number of empirical studies that support this idea. See Pande (2003); Chattopadhyay and Duflo (2004); Lee, Moretti, and Butler (2004); Jones and Olken (2005); and Besley, Persson, and Sturm (2005).

${ }^{11}$ The dataset that is most closely related to the purpose of this study is the one constructed by Przeworski et al. (2000) for the period from 1950 to 1990. There are, however, two differences. First, Przeworski et al. (2000) do not require universal suffrage to qualify a country as democratic. Second, they require multiparty elections not only for executive office but also for legislature. If their dataset covered the period up to present, I would only need to collect information on universal suffrage because Przeworski et al. (2000) provide information on multiparty elections for executive office and for legislature separately. Boix and Rosato (2001) and Cheibub and Gandhi (2004) update Przeworski et al. (2000)'s data to more recent years, but they do not provide such disaggregated information as necessary to fit the purpose of this study.
} 
ernment) has been elected in multiparty elections with universal suffrage, and whether opposition parties are legal. I consult Nohlen et al. (1999) and Africa South of the Sahara (London: Europa Publications, various issues) for collecting such information. ${ }^{12}$

This coding procedure reveals the following pattern of the evolution of democracy in the 28 countries. Among 23 countries that became independent by the 1960s, 13 were democratic at independence. All these countries, however, experienced the collapse of democracy either by a military coup or by the banning of opposition parties by the early 1970s. Around 1980, three countries (Ghana, Nigeria, and Uganda) became democratic, but all of them saw military coups toppling democratic governments by the mid1980s. During the 1990s, 11 countries were democratized (see column (1) in Table 1 for the list of these democratized countries).

I exploit these 11 episodes of democratization during the 1990s to estimate the effect of democracy in the following analysis. ${ }^{13}$ I create a dummy variable for democratization which is equal to one for years after the year of democratization in these 11 democratized countries (listed in column (1) of Table 1). This ensures that the democratization dummy is equal to one only if all babies born in a given year are exposed to democracy. ${ }^{14}$

For the consistent estimation of the effect of democratization, the 11 democratized countries must be comparable to the other 17 countries in terms of determinants of infant mortality. Figure 2 shows the geographical distribution of democratized countries during the 1990s. It reveals that democratized countries are not concentrated in a particular region, which ensures the comparability of democratized and non-democratized countries

\footnotetext{
${ }^{12}$ See the Data Appendices A and B (available on my website) for more details on the measurement of democracy.

${ }^{13}$ Namibia and Zimbabwe became independent in 1990 and 1980, respectively, with the chief executive elected in multiparty elections with universal suffrage. Opposition parties have been legal in both countries until present. However, it is impossible to disentangle the effect of democratization from that of independence in these two cases. Therefore, I treat the two countries as non-democratized ones by dropping the sample before the year of independence.

${ }^{14}$ There are three countries in which democratization was followed by coups within the sample period (Comoros, Lesotho, and Niger). I do not treat these cases differently for two reasons. First, in each case, a fresh multiparty election for executive office immediately followed (often due to international pressure). Second, treating these cases differently could cause the selection bias: the remaining "permanent" democratizations are permanent because they are successful in bringing about benefits to the population while "broken-down" democratizations broke down because they failed to do so. Limiting attention to only those "permanent" democratization may cause an upward bias in the estimation of the beneficial effect of democratization.
} 
in terms of geographical factors. Columns (1) and (2) in Appendix Table A1 show how comparable the two groups of countries are in terms of country-level variables that are likely to be associated with infant mortality. Differences in the means of these variables are never statistically significant at the conventional level.

\subsection{Micro Data on Infant Mortality}

The data on infant mortality at the individual level is obtained from the Demographic and Health Surveys (DHS), conducted by ORC Macro in various developing countries since the late 1980s with funding from the U.S. Agency for International Development (USAID). ${ }^{15}$ The DHS questionnaire consists of standardized components and country-specific ones. Using the standardized part of the questionnaire allows researchers to compile cross-country micro datasets.

In each DHS survey, a nationally representative sample of women of child-bearing age (15 to 49) are interviewed about the survival of almost all the children they gave birth to in the past, including those who died by the time of the interview. ${ }^{16}$ From this recall data, I construct a panel dataset of mothers where the time dimension is the year of child birth given by each mother. Therefore, as long as at least one round of survey was conducted in a country, a panel dataset of mothers is available for that country. ${ }^{17}$

To investigate the effect of democratization on infant mortality in subSaharan Africa, I select 28 DHS surveys, one for each sub-Sahara African country, conducted since $1996 .{ }^{18}$ If there are more than one surveys available in a country during this period, I select the latest survey to maximize

\footnotetext{
${ }^{15}$ See www.measuredhs.com (the DHS survey website) for more details and for downloading data files. The DHS data is widely used by demographers and public health researchers. Economic research using the DHS data includes Pitt (1997), Dow, Philipson, and Sala-i-Martin (1999), and, most recently, Young (2005).

${ }^{16}$ The maximum number of children for each interviewed mother in the dataset is 20 . In the sample, however, there is only one mother giving birth to more than 20 children.

${ }^{17} \mathrm{An}$ issue with the recall data is its accuracy. The DHS survey interviewers conduct a number of probes to ensure the quality of birth history data based on interviewees' memory. See page 14 of ORC Macro (2006).

${ }^{18}$ I thank Bernard Barrere for granting access to Mauritania DHS survey results. The 28 countries in the sample are fairly representative for the whole of sub-Saharan Africa. Columns (3) and (4) in Appendix Table A1 compare the means of various country-level variables that are likely to be associated with infant mortality between the 28 sample countries and all the countries in the region. There is no systematic difference between the two.
} 
the number of post-democratization years covered in the sample. ${ }^{19}$ See Appendix Table A2 for the list of surveys used in the analysis. ${ }^{20}$

The 28 DHS surveys provide a sample of 693,495 children born to 171,110 mothers with the year of birth of children spanning from 1958 through 2005 . From this, the following observations are dropped: (i) children born before the year of independence of their country and (ii) children born within 12 months before their mother's interview. Children of type (i) are excluded in order to prevent the effect of colonial rule from muddling the comparison of dictatorship and democracy. Children of type (ii) might have died before reaching the age of one even if they were alive at the time of their mother's interview, which results in measurement error. Dropping these observations results in the base sample of 643,846 children born to 161,876 mothers with the year of birth of children spanning from 1960 and 2004 .

To measure individual-level infant mortality, a dummy for whether a child dies before turning the age of one year is constructed. As the literature suggests that determinants of infant death within the first month of life (known as neonatal mortality) differ from those for the rest of the first year of life ${ }^{21}$ a dummy for whether a child dies before turning the age of one month is also constructed. These two dummy variables are the dependent variables in the following analysis. Other characteristics of babies used in the analysis below are their sex, whether or not they are born in multiple birth (i.e. twins, triplets, etc.), their birth order, the age of their mother at their birth, the preceding birth interval (how many months have passed when they are born since their mother gave birth to the previous child), the ownership of consumer durable goods by their household at the survey date, how many years their mother has lived in the surveyed community when she is interviewed, the level of their mother's education, the area of residence (urban or rural), and their mother's ethnicity.

Note that, due to the nature of retrospective data, children born to the mothers who are dead or not eligible to be surveyed (i.e. 50 years old or over) at the time of the survey are missing in the sample. If the impact of democratization is systematically different between these missing children

\footnotetext{
${ }^{19}$ One exception is Senegal, for which I use the 1997 survey instead the latest survey in 1999, because the 1999 survey data is not recoded and the codebook is written in French.

${ }^{20}$ Five more African countries (Botswana, Burundi, Central African Republic, Liberia, and Sudan) conducted the DHS survey before 1996. Given that democratization in Africa took place mostly in the early 1990s, however, these surveys are not useful to investigate the effect of democratization. In addition, Eritrea conducted the DHS surveys in 1995 and in 2002. However, access to survey results is restricted and I have not managed to gain permission.

${ }^{21}$ See, for example, Razzaque, Alam, Wai, and Foster (1990).
} 
and those in the sample, all the results in this paper will suffer from sample selection bias. However, there is no a priori reason for why the impact of democratization differs between these two types of children.

\subsection{Summary Statistics}

Table 2 shows summary statistics for variables used in the analysis. Column (1) provides sample means for all countries in the sample; column (2) for babies born in democratized countries until the year of democratization; column (3) for babies born in democratized countries after the year of democratization; column (4) for babies born in non-democratized countries. The infant mortality rate is 10 percent of live births on average for all the 28 countries in the sample. The neonatal mortality rate is 4.7 percent, indicating that nearly half of infant deaths occur within the first month after birth.

Figure 3 plots sample mean infant mortality rates by year for democratized and non-democratized countries. It reveals that non-democratized countries consistently have lower infant mortality rates than democratized countries, with the gap widening in the early 1980s. This gap, however, dramatically disappears by the mid-1990s, when most of the 11 democratization episodes already took place. Figure 3 also shows that infant mortality has been on the decline for both groups of countries with non-democratized countries having a steeper downward trend. This difference in the trend between the two groups of countries will bias the democracy coefficient upwards, going against the finding that democratization has reduced infant mortality.

Figures 4 and 5 show sample mean infant mortality rates by year for each country. While the overall infant mortality has been on the decline as shown in Figure 2, each country exhibits its own trend in infant mortality.

\section{Empirical Analysis}

\subsection{Method}

To investigate whether democratization has reduced infant mortality, I estimate the following equation:

$$
y_{i m c t}=\alpha_{m}+\beta_{t}+\gamma D_{c t}+\delta_{c} T R E N D_{c t}+\mathbf{X}_{i m c t} \theta+\varepsilon_{i m c t},
$$

where $y_{\text {imct }}$ is a dummy equal to one if baby $i$ who is born to mother $m$ in country $c$ in year $t$ dies before reaching the age of one year (or one month if 
the outcome of concern is neonatal mortality), $\alpha_{m}$ is a mother fixed effect, and $\beta_{t}$ is a birth-year fixed effect. $D_{c t}$ is a dummy variable equal to one if country $c$ is democratized by the beginning of year $t$. The term $\delta_{c} T R E N D_{c t}$ represents a linear time trend specific to country $c{ }^{22} \mathbf{X}_{\text {imct }}$ is a vector of exogenous covariates. In the base regression, $\mathbf{X}_{\text {imct }}$ includes dummies for baby girls and for multiple birth (i.e. twins, triplets, or quadruplets). The sex of babies may affect their survival if the return to raising children for their parents is different between boys and girls. ${ }^{23}$ Multiple birth results in an unexpected reduction in the amount of available household resources per child, which may increase the likelihood of infant death. ${ }^{24}$ Although there is no a priori association between democratization and the likelihood that female babies or twins are born, controlling for these exogenous characteristics of babies reduces the error variance, and thus increases the precision of estimation of coefficients of interest. Standard errors are clustered at the country level to take into account any arbitrary correlations of the error term $\varepsilon_{\text {imct }}$ across babies born in country $c$ in year $t$ and over time in country $c .^{25}$

The parameter of interest, $\gamma$ in equation (1), measures the average difference in changes in the probability of the death of babies born to the same mother between those countries that are democratized and those that are not. Under the assumption that, after controlling for mother fixed effects, country-specific linear trends, and exogenous covariates, changes in infant mortality in non-democratized countries provide a counterfactual for democratized countries (i.e. changes in infant mortality that would occur if there were no democratization), $\gamma$ represents the effect of democratization on infant mortality. Specifically, the error term, $\varepsilon_{i m c t}$, must satisfy the following equation:

$$
E\left(\varepsilon_{i m c t} \mid \mathbf{D}_{c}, \mathbf{D}_{t}, \alpha_{m c}, \beta_{t}, \delta_{c}, \mathbf{X}_{m c}, \mathbf{X}_{t}\right)=0,
$$

where $\mathbf{D}_{c}$ and $\mathbf{X}_{m c}$ are the vectors containing $D_{c t}$ and $\mathbf{X}_{i m c t}$, respectively, for

\footnotetext{
${ }^{22}$ As there are plenty of observations before democratization (compare columns 1 and 9 in Table 1), linear trends are unlikely to pick up the post-democratization trend (Wolfers 2006).

${ }^{23}$ There is mixed evidence on gender bias in infant and child mortality in sub-Saharan Africa. See Klasen (1996) and references therein.

${ }^{24}$ Pison (1992) reports that in sub-Saharan Africa twins are 3 to 4 times as likely to die within the first year of life as singletons are.

${ }^{25}$ I specify the linear probability model. Conditional fixed effects logit estimation yields similar results in terms of the sign and statistical significance of the estimated democracy coefficient. However, its consistency requires no serial correlation in the error term, which is unlikely to hold in the present context (see Zenger 1993, for example). In addition, the coefficient estimates in fixed effects logit models are difficult to interpret.
} 
all $t$ in which mother $m$ gives birth, and $\mathbf{D}_{t}$ and $\mathbf{X}_{t}$ the vectors containing $D_{c t}$ and $\mathbf{X}_{i m c t}$ for all $c$. Due to the presence of mother and year fixed effects as controls, $\varepsilon_{\text {imct }}$ must be uncorrelated not only with the contemporary status of democracy $D_{c t}$ but also with the past and future status of democracy when the same mother gives birth to another child, and with all other countries' status of democracy in year $t$.

Unobservable "prerequisites for democracy" plague all empirical studies that try to identify the effect of democracy. Unlike cross-country regression analysis, however, unobservable time-invariant characteristics of countries such as geography, history and culture are not the source of violation of the identifying assumption represented by equation (2) because the set of mother fixed effects in each country captures such country fixed effects. Among time-variant prerequisites at the country level, one of the major factors that may drive both democracy and infant mortality is the level of education among adults. ${ }^{26}$ However, change in the stock of education in the adult population does not affect equation (2) because the effect of mothers' education on infant mortality is captured by mother fixed effects. ${ }^{27}$ This is the main advantage of using individual-level data instead of country-level data in the investigation of the effect of democracy. In the country-level regression analysis, controlling for a time-variant measure of education such as the average years of schooling in the adult population does not help identification because it is correlated with the error term by some lags. For example, an improvement in child health that also boosts educational attainment (e.g. Miguel and Kremer 2004) leads to an increase in the stock of education some years later. This breaks down the strict exogeneity assumption on the error term for consistency in fixed effects estimation.

Another time-variant factor that may drive both democracy and infant mortality is income. ${ }^{28}$ Due to the lack of data on earnings of each mother's

\footnotetext{
${ }^{26}$ See section 3.3 of Strauss and Thomas (1996) for a survey on the effect of parental education on child health. For a classical account of education as the main drive for democracy, see Lipset (1959). For the latest debate on this issue, see Acemoglu, Johnson, Robinson, and Yared (2005a) and Glaeser, Ponzetto, and Shleifer (2006).

${ }^{27}$ Among babies with their mother's years of schooling available, there are 2,351 babies who are not the only child and born before the year of completion of their mother's study (calculated as the number of years of schooling plus 6, assuming that primary school begins at the age of 6 ). There are 6,896 babies whose mother's years of schooling is not available. Therefore, the level of maternal education differs across different babies born to the same mother only for at most 1.4 percent of the sample observations.

${ }^{28}$ See section 3.4 of Strauss and Thomas (1996) for a survey on the effect of income on child health. A recent empirical investigation of the income-democracy link is found in Acemoglu, Johnson, Robinson, and Yared (2005b).
} 
household over time, this remains a major concern for identification in this analysis. In section 3.3, I deal with this issue in a couple of ways.

\subsection{Main Results}

Table 3 reports estimated coefficients on the democratization dummy by adding controls one by one. Column (1) only controls for year fixed effects. The democracy coefficient is positive but not significantly different from zero. Column (2) additionally controls for country fixed effects. The democracy coefficient becomes negative and statistically significant. Given that nondemocratized countries have lower infant mortality rates on average than democratized countries (see Table 2 and Figure 3), the coefficient estimate in column (1) picks up such cross-country variation, offsetting within country variation shown in column (2).

Column (3) controls for mother fixed effects instead of country fixed effects. The democracy coefficient becomes larger in absolute terms. This result indicates that the composition of mothers changes after democratization with their characteristics worsening in relation to infant mortality. A possible explanation is that women becoming mothers after democratization are less healthy because they were born in the 1980s, when economic recessions may have impoverished their parents, and grew up with insufficient nutrients. Economic recessions may have led to democratization in the early 1990s in the democratized countries. ${ }^{29}$ The country fixed effects estimation, therefore, picks up such omitted factors, yielding the biased estimate for the democracy coefficient.

Column (4) additionally controls for country-specific linear trends. The democracy coefficient remains almost the same and statistically significant. This result shows that the coefficient estimate in column (3) does not reflect a steeper declining trend in infant mortality in democratized countries than in non-democratized countries. ${ }^{30}$

Finally, column (5) adds exogenous covariates (dummies for female babies and for multiple births) in the set of control variables. Democratization is followed by a reduction in the infant mortality rate by 1.8 percentage points, which is as much as 18 percent of the sample mean. To gauge the

\footnotetext{
${ }^{29}$ Bratton and van de Walle (1997) find that democratization in Africa followed frequent political protests, which were in turn more frequent the more often the government adopted structural adjustment programmes in the 1980s.

${ }^{30}$ Controlling for quadratic or cubic country-specific trends makes the democracy coefficient estimate smaller and insignificant, suggesting that the effect of democratization is not a sudden change in infant mortality.
} 
magnitude of this fall, recall Figure 1 . The 1.8 percentage point decline roughly corresponds to the fall in infant mortality in the whole of SubSaharan Africa between 1980 and 2000.

Column (6) reports the result for neonatal death in the same specification as in column (5). The probability that a mother sees her baby die within the first month of life falls after democratization by 1 percentage point, 21 percent of the sample mean. A sizable portion of the fall in mortality within the first year of life is therefore due to the fall in mortality within the first month of life.

The democracy coefficient estimates in columns (5) and (6), however, may not reflect the effect of democracy. Given that democratization in Africa often followed economic stagnation, it may be the case that infant mortality temporarily went up due to impoverishment of their mothers before democratization. If this is the case, the democratization coefficient is estimated to be negative even if democratization has no impact. Alternatively, infant mortality may begin to drop some years before democratization due to changes in some socio-economic prerequisites for democracy. We then spuriously attribute such an effect to the one of democratization. To deal with these concerns, I estimate the dynamics of infant mortality before and after democratization. I replace $D_{c t}$ in equation (1) with the set of yearwise dummy variables which are equal to 1 if $n$ years have passed since the year of democratization, where $-5 \leq n \leq 3$, and another dummy variable equal to 1 if 4 years or more have passed since the year of democratization. ${ }^{31}$ Figure 6 plots the estimated coefficients on these dummies (see also Appendix Table A3) and shows the 95 percent level confidence intervals. ${ }^{32}$ These are interpreted as percentage point changes in infant mortality, relative to changes in non-democratized countries, compared to the period until 6 years before democratization. There is no statistically significant change in infant mortality until the year of democratization. This result supports the interpretation of estimated democracy coefficients in columns (5) and (6) of Table 3 as the effect of democratization.

Figure 6 also indicates that infant mortality drops immediately after democratization and continues to fall subsequently. The immediate fall in

\footnotetext{
${ }^{31}$ I lump together 4 or more years after democratization because three of the 11 democratized countries (Madagascar, Nigeria, and South Africa) have observations only until 3 years after democratization. Therefore, estimated change in infant mortality from three years after democratization to four or more years after can be due to change in the composition of countries in the sample.

${ }^{32}$ This type of analysis is increasingly common in labour economics. See Jacobson, LaLonde, and Sullivan (1993), Autor (2003), and Wolfers (2006).
} 
infant mortality may reflect the promotion of awareness among mothers on healthy behavior such as hand-washing. The subsequent additional decline in infant mortality may indicate that health infrastructure such as sanitation facilities and health clinics are now put in place after a couple of years of preparation. These interpretations assume that health policy changes immediately after democratization. If democratic policy-making tends to be slow because mustering support from the majority of legislators takes time, this assumption is unlikely to hold. However, given that the chief executives of government have large discretion over policy-making in Africa, as the literature on African politics suggests, the immediate change in health policy after democratization is not entirely implausible.

The estimation results have so far concerned the aggregate effects. The effects of democratization, however, may not be homogeneous among the population. Two characteristics of mothers are likely to yield heterogeneity in changes in infant mortality after democratization: their level of education and their ethnicity. The effect of democratization may be stronger for uneducated mothers, if the democratized government provides knowledge on health to tackle infant mortality and if educated mothers are already aware of it. Mothers who do not share their ethnicity with the dictator who ruled the country until democratization may also benefit more from democracy. Under dictatorship, they may have been excluded from policy-making process. Their desire for the survival of their babies, therefore, may not be heard by the government. ${ }^{33}$ After democratization, these mothers gain the right to vote in contested elections for executive office. As a result, the government has an incentive to help their babies survive. On the other hand, mothers from the dictator's ethnic group may enjoy public health interventions even under dictatorship. Consequently, the effect of democratization on the reduction of infant mortality is likely to be stronger for babies born to mothers from ethnic groups not in power under dictatorship. ${ }^{34}$

\footnotetext{
${ }^{33}$ African countries are known to be highly heterogeneous in terms of ethnicity (Easterly and Levine, 1997), and it is often argued that political leaders favour their own ethnic groups against the others (see, for example, Bates 1983).

${ }^{34}$ The same argument may explain Almond, Chay, and Greenstone (2003)'s finding that infant mortality among black people converged to the level of infant mortality for white people in the United States from 1965 to 1971 via improved access to hospitals for black people. Although Almond et al. (2003) attribute this infant mortality convergence to the prohibition of racial discrimination in hospital care by a U.S. Appeals Court decision in 1963 and Title VI of the 1964 Civil Rights Act, the federal Voting Rights Act of 1965, which eliminated poll taxes and literacy tests that had effectively disenfranchised black people (see Besley, Persson, and Sturm 2005), may have also contributed by the logic described here.
} 
The use of micro data allows me to investigate these possibilities. Table 4 reports the estimated impacts of democratization on infant and neonatal mortality by mothers' education level and ethnicity. In columns (1) and (2), I interact the democratization dummy with indicator variables for uneducated mothers (those who never went to school) and for educated mothers (those who at least attended primary school). For both infant mortality and neonatal mortality, it is uneducated mothers who benefit the most from democratization. Babies born to uneducated mothers are less likely to die within the first year (month) of life after democratization than before by 2.3 (1.2) percentage points. The difference in the estimated coefficients of democratization between uneducated and educated mothers (1.4 percentage point for infant mortality and 0.6 for neonatal mortality) is statistically significant at 1 percent level. To gauge the economic significance of these results, note that the difference in the sample average infant (neonatal) mortality between babies born to educated and uneducated mothers is 3.6 (1.9) percentage points (see column (1) of Table 2). Therefore, after democratization, inequality in health in terms of infant mortality between the two groups of babies declines by 39 percent. For neonatal mortality, it is a 32 percent fall in the gap. ${ }^{35}$

The finding that uneducated mothers benefit more from democratization might be driven by the fact that there are more uneducated mothers in rural areas than in urban areas and that democratization has corrected what is often called "urban-bias". Bates (1981) points out that African governments in the 1960s and 1970s - the period when they were more or less autocratic - favoured urban residents against rural ones in terms of the allocation of public resources. ${ }^{36}$ To explore this possibility, I create four dummies for uneducated mothers living in urban areas, educated mothers in urban areas, uneducated mothers in rural areas, and educated mothers in rural areas. ${ }^{37}$

\footnotetext{
${ }^{35}$ These results, however, do not suggest that democratization has no impact for educated mothers. The coefficient on the interaction term between democratization and educated mothers reflects a difference between educated mothers in democratized countries and all mothers in non-democratized countries. If I restrict the sample to babies born to educated mothers and estimate equation (1), then the democracy coefficient is significantly negative, suggesting that educated mothers also benefit from democratization.

${ }^{36}$ Majumdar, Mani, and Mukand (2004) suggest that even a democracy creates urban bias: voters in urban areas are better at observing policy outcomes, and thus more responsive to policy change, than those in rural areas, creating an incentive for policy-makers to favour urban people in the allocation of public resources.

${ }^{37}$ Note that areas of residence refer to mothers' residence at the survey date. For mothers who migrated from rural to urban areas or vice versa, this results in measurement error. If I drop such mothers as I do for column (8) of Table 5 (see section 3.3 below), I obtain similar results.
} 
These four dummies are interacted with the democratization dummy.

Columns (3) and (4) report the results. Uneducated mothers benefit from democratization equally between those living in urban and rural areas, though the estimated coefficient is larger in absolute terms and more precise for rural mothers. The difference between educated mothers living in urban areas and in rural areas is also small. An F-test cannot reject the null hypothesis that there is no difference in the democracy coefficient between urban and rural areas both for uneducated mothers and for educated mothers. These results indicate that uneducated mothers benefit from democratization irrespective of where they live. ${ }^{38}$

In columns (5) and (6), I interact the democratization dummy with dummies for the dictator's ethnic group and the other ethnic groups. To create ethnicity dummies, from various sources I identify the ethnicity of the dictator who ruled the country until the year of democratization and match it with the list of ethnic groups in the DHS surveys. ${ }^{39}$ Ethnic groups that are different from the former dictator's benefit more from democratization. The difference in the magnitude of the democratization effect is statistically significant for both infant and neonatal mortality. On the other hand, the former dictator's ethnic group does not see a statistically significant change in infant and neonatal mortality though the point estimates are negative. A newly elected chief executive, therefore, does not appear to retaliate against the ethnic group in power until democratization. In other words, democratization in Africa does not worsen ethnic conflict. ${ }^{40}$

\subsection{Robustness Checks}

The previous subsection reveals that infant mortality falls after democratization. This finding, however, does not necessarily reflect the effect of democratization on public health policy-making, as argued in section 2 , because other factors may have changed at the same time as democratization.

\footnotetext{
${ }^{38}$ If I include only urban and rural dummies (without interaction with education), the difference in estimated coefficients on these two dummies interacted with democratization is not statistically significant.

${ }^{39}$ See the Data Appendix A on my website for details. Nine countries are dropped from the sample in this analysis because the DHS surveys in these countries do not ask respondents about their ethnicity.

${ }^{40}$ To deal with a concern that there are more educated mothers among the dictator's ethnic group and that this drives the result, I estimated coefficients on the interaction terms of ethnic groups and educational status, like what I did in columns (3) and (4) of Table 4. I cannot reject the null that coefficients for each type of ethnic groups are the same across educational status.
} 
One such factor is mothers' income. Even though democratization does not affect any government health policy, mothers may have become richer after democratization, because democratization, for example, brings about political stability and hence an increased investment. Then they become healthier and thus give birth to healthier babies, and/or babies can afford sufficient nutrient intake, leading to a reduction in infant mortality.

As the DHS surveys do not collect information on earnings by mothers or their household members over time, I cannot directly control for income at the individual level. An indirect way of controlling for change of mothers' income over time is to control for real GDP per capita available in the Penn World Table 6.2. Column (1) of Table 5 reports the estimation result when the logarithm of per capita real GDP and its one-year lag are controlled for. An increase in per capita GDP seems to reduce infant mortality concurrently but not one year after, though both coefficient estimates are not significantly different from zero. The democratization coefficient, on the other hand, remains statistically significant and its size is almost the same as in column (5) of Table 3. This result suggests that the estimated effect of democratization in Table 3 is not driven by the concurrent move in per capita income at the country level.

Another way of checking the robustness to the income hypothesis is to restrict the sample to those babies born to mothers with no assets at the time of the interview. As these mothers are poor at the time of the survey, the only possible trajectories of their personal income in the past are either that they have always been poor since their first child birth or that they used to be better off but have become poorer over time. Therefore, the bias to the democracy coefficient due to unobserved personal income change over time will be, if anything, upward for this subsample of babies. If we still see a significantly negative coefficient on the democracy dummy, then the income hypothesis is less likely to be an alternative explanation of the result found in Table 3, at least for babies born to asset-poor mothers.

The DHS surveys ask the possession of the following consumer durables: radio, television set, refrigerator, bicycle, motorcycle, and car. If a baby's mother owns none of these items, such a baby is retained in the sample. Column (2) of Table 5 reports coefficient estimates for this subsample of babies born to asset-poor mothers. Although it slightly loses precision, the estimated coefficient on the democracy dummy does not change substantially. This result encourages the interpretation of the results in Table 3 as not picking up the effect of change in personal income after democratization. ${ }^{41}$

\footnotetext{
${ }^{41}$ In section 4.3 below, the possibility that growth in personal income drives the results
} 
Another time-variant factor that may confound the effect of democratization on health policy-making is the incidence of a war. Democratization may just bring about peace. Therefore, babies no longer die due to battlerelated causes, or the government can now deliver health services for those living in areas previously controlled by rebels. To deal with this concern, column (3) of Table 5 controls for a war dummy which is equal to one if there is at least 1,000 battle-related deaths per year in a country, obtained from the Armed Conflict Database Version 3-2005b (Gleditsch et al. 2002). The democracy coefficient remains almost the same as in column (5) of Table 3 , suggesting that the estimated effect of democracy does not pick up the effect of peace.

Yet another confounding factor may be foreign aid. Donor countries may become willing to provide more financial resources for democratized countries, but not for non-democratized countries. This increased foreign aid may simply expand the budget set for policy-makers who are always willing to provide public health interventions to reduce infant mortality irrespective of political regimes. Column (4) of Table 5 deals with this concern by additionally controlling for the amount of disbursed official development assistance (in million US dollars, 2004 prices) each country receives in each year, obtained from the OECD Donor Assistance Committee Database 2005. The democracy coefficient remains almost the same as in column (5) of Table 3, suggesting that change in foreign aid does not drive the effect of democratization on infant mortality. ${ }^{42}$

Democratization in sub-Saharan Africa took place in the 1990s, when the HIV epidemic began to spread in the region. Although the spread of HIV/AIDS is unlikely to affect democratization, the coincidence of timing of the two in Africa may bias the democracy coefficient estimate. Bobat et al. (1999) report that about one-third of children born to HIV-infected mothers become infected as well and that about a third of the infected children die within the first year of life. A crude calculation suggests that a 10 percent increase in the HIV infection rate among pregnant women leads to a 1.1 percent increase in the infant mortality rate. It may be the case that the estimated coefficients on democratization reported in Table 3 are biased because mothers who gave birth before democratization subsequently become infected with HIV and give birth to another child after democratization. Column (5) of Table 5 controls for United States Census Bureau's estimates

will be revisited.

${ }^{42}$ Controlling for the amount of foreign aid committed to the health sector, water supply and sanitation, developmental food aid, or emergency food aid (obtained from the OECD Creditor Reporting System Database 2005) does not change the result, either. 
of annual HIV-infection rates amongst pregnant women at the country level, used by Young (2005). ${ }^{43}$ I fill missing values with zero because the estimates are missing before the outbreak of HIV infection in the late 1970s and the early 1980 s. ${ }^{44}$ The HIV infection rate among pregnant women at the country level is positively correlated with infant mortality though it is not statistically significant. The point estimate for the democracy coefficient as well as its precision does not change much, indicating that the spread of HIV infection does not significantly bias the estimation results.

Column (6) in Table 5 deals with another concern for the consistency of the estimation of the effect of democracy. As the source of identification of the democracy effect comes from democratization, not from the collapse of democracy, ignoring the effects of birth order and the mother's age at birth may result in estimation bias. Children of higher birth orders may be more likely to die because he or she needs to compete with many other children for household resources. ${ }^{45}$ Alternatively, children of lower birth orders, especially the first child, may be more likely to die because mothers are not experienced in child-bearing or because labor tends to be prolonged during the first birth-giving, predisposing to birth injury and respiratory distress syndrome of babies. In addition, the demographic literature finds that babies born to very young mothers are associated with higher infant mortality (e.g. Da Vanzo et al. 1983). If babies born later are more likely to survive irrespective of democracy, I will find a spurious association between democracy and infant mortality. To deal with this concern, I extract information on birth order and the age of mothers at birth from the DHS surveys. I create dummies for each birth order from the second to the ninth as well as the tenth or higher with the first birth as the omitted category. For the age of mothers, I create dummies for whether the mother is aged at her child birth in their 20s, in their 30s, or in their 40s with giving birth under the age of 20 as the reference category. Column (6) in Table 5 reports the result after controlling for these dummies. The democracy coefficient becomes slightly smaller in absolute terms, suggesting that some of the estimated democracy effect captures the effect of birth order and mothers' age. But the size of

\footnotetext{
${ }^{43}$ I thank Alwyn Young for sharing the HIV data.

${ }^{44}$ Note that the estimates are missing for Comoros, Madagascar, and Mauritania because the Census Bureau does not consider these countries as generalized epidemics (i.e. HIV is firmly established in the general population). I assign a series of zeros to these three countries. The result does not essentially change if I drop these three countries from the sample.

${ }^{45}$ Behrman (1988) finds that parents favour older children in the allocation of nutrients in rural India.
} 
the coefficient remains sizable and statistically significant.

Another potentially confounding factor is fertility. After democratization, the government may have launched population control campaign, leading to longer birth spacing. The demographic literature finds that a child who has a sibling born within the preceding two years is associated with higher infant mortality (e.g. Hobcraft et al. 1985). Column (7) of Table 5 controls for a dummy equal to one if the preceding birth interval obtained from the DHS surveys is less than 24 months. Consistent with the literature, short birth spacing is associated with higher infant mortality. The democracy coefficient, however, remains statistically significant though its size becomes slightly smaller. This result indicates that the effect of democratization on infant mortality is not totally driven by change in population control policy.

Finally, the estimated effect of democratization in Table 3 may simply pick up the effect of migration of mothers to places where better health care provision is available around the time of democratization. If this is the case, then infant mortality can fall without any change in public health intervention after democratization. To deal with this concern, column (8) of Table 5 restricts the sample to babies conceived in the surveyed community, by dropping those babies who were born before one year had passed since their mother migrated to the surveyed community and those babies whose mother does not provide information on her migration. ${ }^{46}$ Babies born during the first year since their mother's migration are dropped because their survival may be affected by poor antenatal care provision during their mother's pregnancy at the previous place of residence. For this subsample of babies, the democratization coefficient is almost the same as the one in column (5) of Table 3, suggesting that the estimated effect of democratization does not pick up the effect of migration to places with better health care.

\subsection{What Type of Democracy Matters?}

As discussed in section 2, I measure democratization in a specific way. Then I find that it has reduced infant mortality. However, the measurement of democracy in this paper may be a noisy measure of the exact features of democracy that really drive infant mortality down.

In section 2, I mentioned that it is an empirical question whether the replacement of the chief executive is necessary for the introduction of con-

\footnotetext{
${ }^{46}$ As the DHS surveys for Chad, Cote d'Ivoire, and Guinea do not ask any respondent how many years she has lived in the surveyed community, these three countries are dropped from the sample.
} 
tested elections with universal suffrage to reduce infant mortality. Column (1) of Table 1 lists the year of the introduction of multiparty elections with universal suffrage for executive office, based on the information I collect. Non-democratized countries except Namibia, Rwanda, Senegal, and Zimbabwe also introduced multiparty elections in the 1990s. To see if the introduction of multiparty elections for executive office alone is sufficient to reduce infant mortality, I create a dummy variable which is equal to one for 13 non-democratized countries after the year of the first multiparty election in the 1990s listed in column (1) of Table 1. Then I estimate equation (1) with this dummy variable included as an additional regressor. Column (1) of Table 6 reports that the multiparty election dummy coefficient is not statistically different from zero while the democracy coefficient remains significant. The equality of coefficients on these two dummies is rejected at 5 percent level. This result implies that the introduction of multiparty elections per se does not affect infant mortality. The chief executive needs to be replaced for multiparty elections to bite.

On the other hand, the estimated effect of democratization may pick up the effect of leadership change per se, irrespective of whether the change is due to the introduction of multiparty elections or not. To deal with this concern, I identify seven episodes of non-democratic leadership change in the late 1980s and the early 1990s among the 17 non-democratized countries. These changes are either due to a military coup or to the death or voluntary resignation of a dictator. Then the new chief executives stay in office until the end of the sample period. I create a dummy variable which is equal to one for years after these seven non-democratic changes in the chief executives. Column (2) additionally controls for this dummy to equation (1). It shows that non-democratic leadership change does not significantly affect infant mortality while the estimate of the democratization effect remains the same. The equality of coefficients on these two dummies is rejected at 10 percent level. ${ }^{47}$ This result indicates that the estimated effect of democratization does not solely reflect the effect of leadership change. The introduction of multiparty elections and the replacement of the chief executive are complementary in reducing infant mortality.

Columns (3) to (5) of Table 6 check if the estimated effect of introducing multiparty elections with the replacement of the chief executive captures the effect of other features of democracy. Column (3) controls for the degree

\footnotetext{
${ }^{47}$ The large standard error for the non-democratic leadership change dummy is due to Rwanda: infant mortality went up sharply before leadership change in 1994 (see Figure 5). If I drop Rwanda from the sample, the equality of coefficients on the democracy and leadership change dummies is rejected at 1 percent level.
} 
of executive constraints taken from the POLITY IV dataset. This variable takes values from 1 to 7 with 7 as the highest degree of constraint. The coefficient on this variable is not statistically different from zero while the democracy coefficient remains significantly negative. ${ }^{48}$ This result suggests that unlike its effect on property rights enforcement (North and Weingast 1989; Acemoglu, Johnson, and Robinson 2001), constraints on the chief executive do not matter for infant mortality.

Columns (4) and (5) explore the possibility that the measurement of democracy in this paper may capture the degree of human rights protection. Column (4) additionally controls for the degree of civil liberty restriction (scaled from 1 to 7) taken from Freedom House's Freedom in the World, an annual survey of political rights and civil liberties since 1972. Column (5) controls for two dummies which are equal to one if press freedom is rated as "Free" and as "Partly Free", respectively, as oppose to "Not Free" by Freedom House's Freedom of the Press, an annual survey of press freedom since 1980. Both columns show that what matters for infant mortality is not human rights protection or press freedom but the way in which the chief executive of the government is chosen. ${ }^{49}$

Finally, Table 7 provides estimation results when I measure the year of democratization based on widely used democracy indicators: the POLITY2 score from the POLITY IV dataset and Freedom House's Political Rights Index. These two indicators assign a score (-10 to 10 for the POLITY2 score and 7 to 1 for the Political Rights Index) for each country-year by aggregating different dimensions of democracy. ${ }^{50}$ An implicit assumption underlying the construction of these democracy indicators is that each element of democracy is a substitute for each other. This assumption may not hold true depending on which outcome we expect democracy to have an impact on. Section 2 above, for example, discusses the complementarity of contested elections and universal suffrage in relation to public health policy-making.

Columns (2) to (7) of Table 1 show the list of years of democratization in the 1990s by using either of these two democracy indicators with different

\footnotetext{
${ }^{48} \mathrm{As}$ the POLITY IV dataset does not measure the degree of executive constraints for year 2004 and for country-years in which a country is occupied by foreign powers, the central political authority collapses, or a country is undergoing the transition of a political regime, about 32,000 observations are dropped from the sample. Change in the size of the democracy coefficient is mainly due to this change in the sample.

${ }^{49}$ The smaller size (in absolute terms) of the democracy coefficient in column (5) is due to change in the sample. The press freedom variables are not available before 1980 .

${ }^{50}$ Note that Freedom House's Political Rights Index becomes smaller if a country becomes more democratic. The opposite is true for the POLITY2 score.
} 
cut-off points. ${ }^{51}$ I create a democratization dummy equal to one for years after the year of democratization listed in Table 1 for each cut-off value of each indicator. As both indicators suggest that some countries became nondemocratic after they were democratized in the 1990s, I also create a dummy variable which is equal to one for years after the collapse of democracy in the 1990 s, in order to check if the effect of democratization on infant mortality persists even after democracy collapses.

Columns (1) to (6) of Table 7 show the estimated coefficients on these democratization dummies for infant mortality. Two main results emerge. First, the democracy coefficient becomes statistically significant only when the cut-off point for a country to be democratic is the most generous (5 for the Political Rights Index and 0 for the POLITY2 score). This result suggests that the minimal level of democracy is sufficient to reduce infant mortality, although what constitutes such a minimal level of democracy is unclear due to the nature of these democracy indicators. Second, the coefficient on the collapse of democracy is negative and not statistically different from the democracy coefficient (except for column 1). This second result may be interpreted in two ways. Health infrastructure and clinics brought in place by democratization do not disappear even after the collapse of democracy, at least not so quickly. Another interpretation is that the way African countries were democratized is different from the way some of them experienced the collapse of democracy. If some elements of democracy have an impact on infant mortality but others do not, it is natural to see this asymmetric effect between democratization and the collapse of democracy.

Unlike Freedom House, which makes public disaggregated scores of democracy only from 2006, the POLITY IV dataset does provide disaggregated indicators of democracy for all years available in the dataset, allowing researchers to aggregate them in a way that is consistent with theory in their mind. I use variables EXREC and PARCOMP to construct a democracy dummy that is as close as possible to the definition of democracy adopted in this paper. Specifically, a country-year is treated as democratic if EXREC is 7 or 8 and if PARCOMP is 3 or higher. The first condition roughly corresponds to the requirement of multiparty elections for executive office while the second is largely consistent with universal suffrage and the existence of legal opposition parties. ${ }^{52}$ Column (8) of Table 1 lists the years of democ-

\footnotetext{
${ }^{51}$ When choosing the cut-off points for the POLITY2 score, I follow the literature: score 0 is used by works summarized in Persson and Tabellini (2006); score 4 by Glaeser, Ponzetto, and Shleifer (2005). Political scientists often regard a country as democratic if its POLITY2 score is seven or higher (e.g. Epstein et al., 2003).

${ }^{52}$ See the Data Appendix A (available on my website) for more details.
} 
ratization in the 1990s based on the above criteria. It is very similar to the years of democratization based on the POLITY2 score being positive though it completely ignores the degree of executive constraints, one component of the POLITY2 score. I again create a democratization dummy which is equal to one for years after these years of democratization as well as the dummy for the collapse of democracy. Column 7 of Table 7 reports the estimation result when I use these dummies as regressors. The estimated coefficient on the democracy dummy is significantly negative, indicating that democratization reduces infant mortality by 1.5 percentage points. The point estimates for the democracy coefficient in columns (1) to (6) are smaller than this or the one in column (5) of Table 3, suggestive of attenuation bias due to measurement error.

\section{Pathways}

Estimation results in the previous section show that democratization has reduced infant mortality in sub-Saharan Africa. In this section, I provide some evidence on the mechanisms in which democratization has affected the survival of babies. Table 8 provides summary statistics for dependent variables used in this section.

\subsection{Maternal Health Care}

One key mechanism is likely to be improvements in maternal health care provision. Recall that a sizable portion of the reduction in infant mortality after democratization comes from a fall in the probability of death within the first month of life (Columns (5) and (6) in Table 3). The public health literature finds that, among others, the following two health interventions affect the survival of babies in their first month of life: tetanus toxoid injections to pregnant mothers and child delivery assistance by skilled health professionals. The injection of tetanus toxoid transfers immunity against neonatal tetanus from a mother to her baby in her womb, which has proved to be effective (see Demicheli, Barale, and Rivetti (2005) for a comprehensive review on evidence from randomized trials). ${ }^{53}$ Having a skilled birth

\footnotetext{
${ }^{53}$ In addition to the direct effect of tetanus toxoid injections, Dow, Philipson, and Salai-Martin (1999) empirically show that, in four sub-Sahara African countries during 1986 to 1994, the birth weight of babies born to mothers who received tetanus toxoid is larger than those born to mothers who did not. The birth weight is known as a significant predictor of early childhood survival (e.g. Da Vanzo et al. 1983; Black, Devereux, and Salvanes 2006). Dow et al. (1999) argue that this is because mothers who received tetanus toxoid
} 
attendant present during labor and delivery ensures clean child delivery and, if necessary, resuscitation of newborns. Clean delivery - keeping clean the birth attendant's hands and instruments to cut the umbilical cord - avoids death from neonatal tetanus, and resuscitation prevents death from birth asphyxia (see Bhutta et al. (2005, Table 20) for a review on available evidence).

The literature also finds that more educated mothers are associated with a higher probability of receiving these maternal health care services, suggesting that the valuation of such services is higher for educated mothers than for uneducated ones. ${ }^{54}$ If democratically elected governments lower the cost of health care services, either by charging lower fees, by creating more health clinics to reduce the transportation cost, or by educating mothers about the benefits of such services, an impact will be larger for uneducated mothers, consistent with earlier findings that a fall in neonatal mortality is larger for babies born to uneducated mothers (Column (2) of Table 4).

To see if maternal health care provision is one key mechanism in which democratization has reduced infant mortality in sub-Saharan Africa, I construct a repeated cross-section sample of live birth episodes for 19 sub-Sahara African countries where the DHS survey was conducted more than once since the late 1980s (see Appendix Table A2 for the list of surveys used). ${ }^{55}$ The DHS survey asks a nationally representative sample of women aged 15 to 49 about their live birth episodes during the last few (usually five) years. Each respondent provides information on whether she received tetanus toxoid injections during pregnancy and on who assisted her child delivery. By treating each live birth episode as a single observation, I create the samples of 235,516 and 285,739 live birth episodes for tetanus vaccination and delivery assistance, respectively. ${ }^{56}$ From this I drop live birth episodes for

injections expect better access to vaccination for her child, thus increasing complementary investments in child health during pregnancy.

${ }^{54}$ See, for example, Akin, Griffin, Guilkey, and Popkin (1986) for a cross-sectional evidence from the Philippines.

${ }^{55}$ Chad and Cote d'Ivoire are dropped from the sample though two rounds of the DHS surveys are available, because one of the two surveys for each country lacks information on the migration of mothers, making it impossible to match babies and mothers from different rounds of survey by region of residence without an error. For the same reason, I do not use Zimbabwe 1994 survey. If I include these surveys in the sample by ignoring the lack of information on migration, the result does not change substantially.

${ }^{56}$ I drop Namibia from the sample for tetanus vaccination because its 2000 survey does not ask whether the respondent received tetanus toxoid injections, leaving only one round of survey for the country. An additional difference in the number of observations between the two samples results from the fact that recent DHS surveys collect information on tetanus toxoid injections only for the last live birth while information on delivery assistance 
women who are visitors to the surveyed community or do not provide information on their migration as well as episodes of live birth before women of concern migrated to the surveyed community. Dropping these observations ensures that estimated change in maternal care provision is not due to mothers' migration to areas with better health care services. ${ }^{57}$ The resulting sample consists of 198,567 and 232,809 observations (including those for which outcome variables are missing) for tetanus vaccination and delivery assistance, respectively, with years of live births spanning between 1982 and 2005 inclusive.

In the estimation of changes in the take-up of maternal health care services before and after democratization, I control for fixed effects of mother categories defined by where mothers live (which administrative regions and whether urban or rural areas), their level of education (whether they attended at least primary school or did not go to school at all), and their birth cohort (the year of birth), in order to make this analysis as comparable as possible to the previous infant mortality analysis. ${ }^{58}$ Specifically, I estimate the following equations:

$$
y_{j r c t}=\alpha_{r}+\beta_{t}+\gamma D_{c, t-1}+\varepsilon_{j r c t},
$$

for tetanus vaccination, and

$$
y_{j r c t}=\alpha_{r}+\beta_{t}+\gamma D_{c t}+\mathbf{X}_{j r c t} \theta+\varepsilon_{j r c t},
$$

for delivery assistance, where $j$ refers to a live birth episode, $r$ refers to a mother category by area-education-cohort (as described above), $t$ refers to the year of live birth. $\alpha_{r}$ is a mother-category fixed effect and $\beta_{t}$ is a birthyear fixed effect. $\mathbf{X}_{j r c t}$ is a dummy variable for multiple birth. Standard errors are clustered at the country level. The democracy dummy, defined in the same way as in the infant mortality analysis above, is lagged one year for tetanus vaccination because mothers receive tetanus toxoid injections during the pregnancy. I control for the multiple birth dummy for delivery assistance regression because pregnant women may know they will give birth to twins before delivery and therefore change their valuation for

is collected for all live births during the past few years.

${ }^{57}$ In addition, observations for Namibia before independence (1990) are dropped for the delivery assistance sample.

${ }^{58}$ For example, I control for a fixed effect for educated mothers, born in 1970, living in urban areas of the Ashanti region of Ghana. See Data Appendix C (available on my website) for how I match administrative regions from different rounds of DHS surveys in each country. 
delivery assistance. ${ }^{59}$ Note that this analysis does not aim to estimate the causal effect of democratization on the take-up of maternal health care. The objective is to find a correlation that is consistent with the findings in the infant mortality analysis.

Table 9 shows the estimation results. In columns (1) and (2), I reestimate equation (1) for neonatal mortality by restricting the sample to the 19 countries where maternal health care information is available. The finding that democratization has reduced neonatal mortality, especially for babies born to uneducated mothers, holds for this subsample of countries. In column (3), I estimate equation (3). In column (4), I interact $D_{c, t-1}$ in equation (3) with dummies for educated and uneducated mothers. Although the take-up for receiving tetanus vaccination did not significantly go up on average after democratization, uneducated mothers became more likely to be vaccinated after democratization by 10 percentage points (significant at 10 percent level), 17 percent of the sample mean for uneducated mothers. Columns (5) and (6) report estimation results for delivery assistance. Similarly, although the probability of having a skilled birth attendant present during delivery did not increase significantly after democratization on average, uneducated mothers became more likely to be attended by health professionals after democratization by 7.6 percentage points (significant at 5 percent level), 25 percent of the sample mean for uneducated mothers. These results suggest that one key mechanism in which democratization has reduced neonatal mortality, especially for babies born to uneducated mothers, is improvements in maternal health care provision.

\subsection{Breastfeeding and Sanitation}

Another key mechanism in which democratization has reduced infant mortality in sub-Saharan Africa may be the promotion of breastfeeding. The public health literature identifies breastfeeding as being associated with lower infant mortality through the prevention of death from diarrhea and acute respiratory infection (WHO Collaborative Study Team 2000; Arifeen et al. 2001). ${ }^{60}$ The effect of promoting breastfeeding on infant mortality is likely to be immediate, compared to other public health interventions. This immediate impact is consistent with the finding that infant mortality starts dropping immediately after the year of democratization (Figure 6).

\footnotetext{
${ }^{59}$ I thank Miyuki Horiuchi for pointing this out.

${ }^{60}$ According to Murray and Lopez (1996, Appendix Table 6f), diarrhea and lower respiratory infections accounted for 38 percent of 4.03 million deaths of children under 5 years old in sub-Saharan Africa in 1990.
} 
The provision of sanitation facilities may also be a mechanism in which democratization has reduced infant mortality. The public health literature finds that access to sanitation facilities is associated with a lower child mortality due to diarrhea. ${ }^{61}$ Death from diarrhea is estimated to account for 20 percent of under-5 child mortality in sub-Saharan Africa in 1990 (Murray and Lopez 1996, Appendix Table 6f).

To investigate whether breastfeeding is more likely to be practiced after democratization, I use the same repeated cross-sectional sample of live births episodes as the one used for delivery assistance. The DHS surveys ask the respondent if she ever breastfed each of her children born during the last few years. From this information, I construct a dummy variable equal to one if the mother ever breast-feeds her baby. To assess whether sanitary conditions for infants are improved after democratization, I create a repeated cross-sectional sample of babies born within the past one year before the DHS survey was conducted, including those who died before the survey, and match each baby with information on their household's access to toilets. ${ }^{62}$ The original sample includes 66,244 babies in total. From this, I drop the following observations: babies whose mother is a visitor to the surveyed community; babies born within the first 12 months after their mother moved to the surveyed community; and babies whose mother does not provide information on how many years she has lived in the surveyed community. Dropping these observations ensures that estimation results reflect change in public health service delivery in the same place over time. The final sample consists of 57,634 observations (including those for which information on access to toilets is missing) with survey years spanning between 1987 and 2004 inclusive.

For breastfeeding, equation (4) is estimated with $\mathbf{X}_{j r c t}$ including not only the multiple birth dummy but also the girl dummy, because mothers may change their breastfeeding practice depending on the sex of their babies. For access to toilets, I estimate the following equation:

$$
y_{i r c s}=\alpha_{r}+\beta_{s}+\gamma D_{c s}+\varepsilon_{i r c s},
$$

\footnotetext{
${ }^{61}$ See Esrey et al. (1991) for a survey of available evidence.

${ }^{62}$ By "toilets" I mean the term "flush toilets" in the DHS surveys. According to a commentary on the DHS model questionnaire (Institute for Resource Development and Macro International 1990, p.6), the term flush toilet is defined as "a facility where the toilet is separated from the refuse disposal system by a water seal." This definition of flush toilet "does not distinguish between whether the water seal is maintained by water dumped from a bucket or a plumbing system or whether the disposal system is a pit, septic tank or public sewer system." To avoid the misinterpretation of the term flush toilet, I use the word "toilets" in this paper instead.
} 
where $i$ refers to babies born within one year before the survey date, $r$ refers to mother categories by area-education-cohort (as described above), and $s$ refers to five-year spells $(1985-89,1990-94,1995-99,2000-04)$ in which the DHS survey was conducted. $\alpha_{r}$ is a mother-category fixed effect and $\beta_{s}$ is a five-year period fixed effect (the DHS survey is usually conducted every fifth year with the exact year of survey different from country to country). The democracy dummy, $D_{c s}$, is set to be one if country $c$ is democratized before the DHS survey was conducted during spell $s .{ }^{63}$ As each country has conducted at most four surveys, the standard errors are clustered at the country-year level because its underestimation due to serial correlations in the error term is likely to be negligible. Again note that these regressions do not intend to establish the causal effect of democratization on outcome variables. The aim is to see if there is a correlation between democratization and improvements in health inputs that is consistent with the finding that democratization has an negative impact on infant mortality.

Table 10 shows estimation results. Columns (1) and (2) re-estimate equation (1) for infant mortality for the subsample of the 19 countries with more than one DHS surveys conducted. They show that the main results hold for this subsample. Column (3) estimates equation (4) with the breastfeeding dummy as the dependent variable. The probability that a mother ever breast-feeds her child goes up by 1.1 percentage points after democratization (significant at 5 percent level). The magnitude of this change is not very large, however, because the sample mean probability of breastfeeding is 97.5 percent. Therefore, the promotion of breastfeeding alone does not seem to explain the whole immediate effect of democratization on infant mortality found in Figure 2. It may be that other health practices beneficial for the survival of babies are also promoted along with breastfeeding. Column (5) reports the result for access to toilets. After democratization, the probability that an infant's household has access to toilets goes up by 1.6 percentage points (significant at 5 percent). The size of this increase is large relative to the sample mean access rate of 4.9 percent. Columns (4) and (6) show that the size of changes in breastfeeding practice and access to toilets is not significantly larger for uneducated mothers than for educated mothers. For access to toilets, however, this result can be still consistent with the larger reduction in infant mortality for babies born to uneducated mothers because there is some evidence that maternal education and sanitary facil-

\footnotetext{
${ }^{63}$ Consequently, for example, $D_{c s}$ is zero for Niger during 1990-94 even though its year of democratization (1993) falls into the same five-year spell, because the DHS survey was conducted in 1992.
} 
ities are substitutes: Using data collected in Malaysia in the 1970s, Esrey and Habicht (1988) report that the effect of having toilets on a reduction in infant mortality is larger for illiterate mothers. ${ }^{64}$

\subsection{Affluence}

Finally, I provide evidence that the effect of democratization on infant mortality is unlikely to be due to an increase in affluence of mothers. Using the repeated cross-sectional sample of infants used for estimating changes in access to toilets, I check if an infant's household is more likely to own either of the six consumer durables (radio, television, refrigerator, bicycle, motorcycle, and car) or to have access to electricity after democratization.

Table 11 reports results from estimating equation (5) with dummies for owning each of the consumer durables or having access to electricity as the dependent variables. Columns 1 to 6 show that there is no evidence that an infant's household is more likely to own any of the six consumer durables after democratization than before. If anything, an infant who was born to an uneducated mother is less likely to live in a household with a television set and a refrigerator after democratization (columns 2 and 3 of panel B). If the ownership of a television set and a refrigerator signifies affluence, uneducated mothers have got poorer since democratization. If infant mortality is primarily determined by affluence, this finding cannot explain the earlier result that babies born to uneducated mothers are more likely to survive after democratization. This result also suggests that the estimated increases in access to toilets and in the take-up of maternal health care services by uneducated mothers after democratization are unlikely to be a result from an increase in affluence. Column 7 reports that there is no change in access to electricity before and after democratization, suggesting that democratically elected governments prioritized public health interventions over the electrification of households.

\footnotetext{
${ }^{64}$ Barrera (1990) finds an opposite result for child's height for age: the effects of maternal education and toilet facilities are complementary. Looking at the result (Table 4 , column 5) carefully, however, the type of toilet facilities and its interaction with maternal education does not enter significantly for height for age of children aged under 2 years the most relevant health outcome to my analysis. The reason for this is probably because the absence of excreta and its interaction with maternal education are included as regressors. Coefficients on these two variables show that sanitation and maternal education are substitutes, a result in line with Esrey and Habicht (1988).
} 


\section{Conclusions}

By comparing babies born to the same mother before and after democratization, I find that democratization has reduced infant mortality in sub-Saharan Africa. Various pieces of evidence, taken together, may suggest the following story. After a new chief executive assumes office by winning contested elections under universal suffrage, the government immediately starts promoting practices beneficial for the survival of babies, including breastfeeding. Infant mortality starts dropping. The government also makes maternal health care more accessible. Uneducated women start using it, resulting in a reduction in neonatal mortality, especially for babies born to uneducated mothers. Finally, the government starts investing in the provision of better sanitation facilities. Its effect materializes a couple of years after democratization, pushing infant mortality further down.

These empirical findings convey a powerful message: democratization may be an important means to improve the quality of government and to promote development in some of the poorest countries in the world. To corroborate this implication, future empirical research needs to examine other outcomes and other developing regions. These studies will benefit from exploiting cross-country individual-level panel data on outcomes as this paper does. Otherwise we cannot disentangle the effect of democracy from country-level confounding factors.

More generally, the use of micro panel data can also be applied to estimate the effects on development of other national political institutions and country-wide political events, including decolonization and leadership change under dictatorship. Such studies promise to be a fruitful direction of empirical research in the political economy of development. 


\section{References}

[1] Acemoglu, Daron, Simon Johnson, and James A. Robinson. 2001. "The Colonial Origins of Comparative Development: An Empirical Investigation." American Economic Review, 91:5, pp. 1369-401.

[2] Acemoglu, Daron, Simon Johnson, James A. Robinson, and Pierre Yared. 2005a. "From Education to Democracy?" American Economic Review, 95:2, pp. 44-49.

[3] Acemoglu, Daron, Simon Johnson, James A. Robinson, and Pierre Yared. 2005b. "Income and Democracy." NBER Working Paper, 11205.

[4] Acemoglu, Daron and James A. Robinson. 2000. "Why Did the West Extend the Franchise? Democracy, Inequality, and Growth in Historical Perspective." Quarterly Journal of Economics, 115, pp. 1167-99.

[5] Acemoglu, Daron and James A. Robinson. 2006. "De Facto Political Power and Institutional Persistence." American Economic Review, 96:2, pp. 325-30.

[6] Akin, John S., Charles C. Griffin, David K. Guilkey, and Barry M. Popkin. 1986. "The Demand for Primary Health Care Services in the Bicol Region of the Philippines." Economic Development and Cultural Change, 34:4, pp. 755-782.

[7] Alesina, Alberto, Arnaud Devleeschauwer, William Easterly, Sergio Kurlat, and Romain Wacziarg. 2003. "Fractionalization." Journal of Economic Growth, 8, pp. 155-94.

[8] Almond, Douglas V., Kenneth Y. Chay, and Michael Greenstone. 2003. "Civil Rights, the War on Poverty, and Black-White Convergence in Infant Mortality in Mississippi." Unpublished Paper.

[9] Arifeen, Shams, Robert E. Black, Gretchen Antelman, Abdullah Baqui, Laura Caulfield, and Stan Becker. 2001. "Exclusive Breastfeeding Reduces Acute Respiratory Infection and Diarrhea Deaths Among Infants in Dhaka Slums." Pediatrics, 108:4, E67. (DOI: 10.1542/peds.108.4.e67)

[10] Autor, David H. 2003. "Outsourcing at Will: The Contribution of Unjust Dismissal Doctrine to the Growth of Employment Outsourcing." Journal of Labor Economics, 21:1, pp. 1-41. 
[11] Banerjee, Abhijit V., and Esther Duflo. 2006. "Addressing Absence." Journal of Economic Perspectives, 20:1, pp. 117-32.

[12] Barrera, Albino. 1990. "The Role of Maternal Schooling and its Interaction with Public Health Programs in Child Health Production." Journal of Development Economics, 32, pp. 69-91.

[13] Barro, Robert J. 1973. "The Control of Politicians: An Economic Model." Public Choice, 14, pp. 19-42.

[14] Barro, Robert J. and Jong-Wha Lee. 2000. "International Data on Educational Attainment: Updates and Implications." CID Working Paper, 42 .

[15] Bates, Robert H. 1981. Markets and States in Tropical Africa: The Political Basis of Agricultural Policies. Berkeley: University of California Press.

[16] Bates, Robert H. 1983. "Modernization, Ethnic Competition, and the Rationality of Politics in Contemporary Africa." Donald Rothchild and Victor A. Olunsorola eds., State versus Ethnic Claims: African Policy Dilemmas. Boulder, CO: Westview Press.

[17] Behrman, Jere R. 1988. "Nutrition, Health, Birth Order and Seasonality." Journal of Development Economics, 28, pp. 43-62.

[18] Besley, Timothy and Masayuki Kudamatsu. 2006. "Health and Democracy." American Economic Review, 97:2, pp. 313-318.

[19] Besley, Timothy, Torsten Persson, and Daniel Sturm. 2005. "Political Competition and Economic Performance: Theory and Evidence from the United States." NBER Working Paper, 11484.

[20] Bhutta, Zulfiqar A., Gary L. Darmstadt, Babar S. Hasan, and Rachel A. Haws. 2005. "Community-based Interventions for Improving Perinatal and Neonatal Health Outcomes in Developing Countries: A Review of the Evidence." Pediatrics, 115: pp. 519-617.

[21] Black, Sandra E., Paul J. Devereux, and Kjell G. Salvanes. 2006. "From the Cradle to the Labor Market? The Effect of Birth Weight on Adult Outcomes." Quarterly Journal of Economics, forthcoming.

[22] Bobat, R., H. Coovadia, D. Moodley, and A. Coutsoudis. 1999. "Mortality in a Cohort of Children Born to HIV-1 Infected Women from 
Durban, South Africa." South African Medical Journal, 89:6, pp. 6468.

[23] Boix, Carles, and Rosato, Sebastian. 2001. "A Complete Data Set of Political Regimes, 1800-1999." Unpublished Dataset.

[24] Bratton, Michael. 1998. "Second Elections in Africa." Journal of Democracy, 9:3, pp. 51-66.

[25] Bratton, Michael, and Nicolas van de Walle. 1997. Democratic Experiments in Africa: Regime Transitions in Comparative Perspective. (New York: Cambridge University Press).

[26] Bueno de Mesquita, Bruce, James D. Morrow, Randolph M. Siverson, and Alastair Smith. 2002. "Political Institutions, Policy Choice and the Survival of Leaders." British Journal of Political Science, 32, pp. 559-590.

[27] Chattopadhyay, Raghabendra and Esther Duflo. 2004. "Women as Policy Makers: Evidence from a Randomized Policy Experiment in India." Econometrica, 72:5, pp. 1409-43.

[28] Chaudhury, Nazmul, Jeffrey Hammer, Michael Kremer, Karthik Muralidharan, and F. Halsey Rogers. 2006. "Missing in Action: Teacher and Health Worker Absence in Developing Countries." Journal of Economic Perspectives, 20:1, pp. 91-116.

[29] Cheibub, Jose Antonio and Jennifer Gandhi. 2004. "Classifying Political Regimes: A Six-Fold Measure of Democracies and Dictatorships." Unpublished Paper.

[30] Da Vanzo, Julie, W. P. Butz, and J. P. Habicht. 1983. "How Biological and Behavioural Influences on Mortality in Malaysia Vary during the First Year of Life." Population Studies, 37, pp. 381-402.

[31] Demicheli, V., A. Barale, and A. Rivetti. 2005. "Vaccines for Women to Prevent Neonatal Tetanus." Cochrane Database of Systematic Reviews, 2005:4, Art. No.: CD002959. (DOI: 10.1002/14651858.CD002959.pub2)

[32] Dow, William H., Tomas J. Philipson, and Xavier Sala-i-Martin. 1999. "Longevity Complementarities under Competing Risks." American Economic Review, 89:5, pp. 1358-71. 
[33] Epstein, David L., Robert Bates, Jack Goldstone, Ida Kristensen, and Sharyn O'Halloran. 2003. "Democratic Transitions." Unpublished Paper.

[34] Esrey, Steven A. and Jean-Pierre Habicht. 1988. "Maternal Literacy Modifies the Effect of Toilets and Piped Water on Infant Survival in Malaysia." American Journal of Epidemiology, 127:5, pp. 1079-87.

[35] Esrey, S.A., J. B. Potash, L. Roberts, and C. Shiff. 1991. "Effects of Improved Water Supply and Sanitation on Ascariasis, Diarrhoea, Dracunculiasis, Hookworm Infection, Schistosomiasis, and Trachoma." Bulletin of the World Health Organization, 69:5, pp. 609-621.

[36] Easterly, William and Ross Levine. 1997. "Africa's Growth Tragedy: Policies and Ethnic Divisions." Quarterly Journal of Economics, 112, pp. $1203-50$.

[37] Ferejohn, John. 1986. "Incumbent Performance and Electoral Control." Public Choice, 50, pp. 5-25.

[38] Gauri, Varun, and Peyvand Khaleghian. 2002. "Immunization in Developing Countries: Its Political and Organizational Determinants." World Development, 30:12, pp. 2109-32.

[39] Glaeser, Edward L., Giacomo Ponzetto, and Andrei Shleifer. 2005. "Why Does Democracy Need Education?" NBER Working Paper, 12128.

[40] Gleditsch, Nils Petter, Peter Wallensteen, Mikael Eriksson, Margareta Sollenberg, and Havard Strand. 2002. "Armed Conflict 1946-2001: A New Dataset." Journal of Peace Research, 39:5, pp. 615-37.

[41] Hobcraft, J. N., J. W. McDonald, and S. O. Rutstein. 1985. "Demographic Determinants of Infant and Early Child Mortality: A Comparative Analysis." Population Studies, 39, pp. 363-85.

[42] Jacobson, Louis S., Robert J. LaLonde, and Daniel G. Sullivan. 1993. "Earning Losses of Displaced Workers." American Economic Review, 83:4, pp. 685-709.

[43] Jones, Benjamin F. and Benjamin A. Olken. 2005. "Do Leaders Matter? National Leadership and Growth Since World War II." Quarterly Journal of Economics, 120:3, pp. 835-64. 
[44] Kiszewski, Anthony, Andrew Mellinger, Andrew Spielman, Pia Malaney, Sonia Ehrlich Sachs, and Jeffrey Sachs. 2004. "A Global Index Representing the Stability of Malaria Transmission." American Journal of Tropical Medicine and Hygiene, 70:5, pp. 486-98.

[45] Klasen, Stephan. 1996. "Nutrition, Health and Mortality in SubSaharan Africa: Is There a Gender Bias?", Journal of Development Studies, 32:6, pp. 913-932.

[46] La Porta, Rafael, Florencio Lopez-de-Silanes, Andrei Shleifer, and Robert W. Vishny. 1999. "The Quality of Government." Journal of Law, Economics, \& Organization, 15:1, pp. 222-79.

[47] Lee, David S., Enrico Moretti, and Matthew J. Butler. 2004. "Do Voters Affect or Elect Policies? Evidence from the U.S. House." Quarterly Journal of Economics, 119, pp. 807-59.

[48] Lindberg, Staffan I. 2003. "The Democratic Qualities of Competitive Elections: Participation, Competition and Legitimacy in Africa." Common Wealth 85 Comparative Politics, 41:3, pp. 61-105.

[49] Lipset, Seymour Martin. 1959. "Some Social Prerequisites of Democracy: Economic Development and Political Legitimacy." American Political Science Review, 53:1, pp. 69-105.

[50] Lizzeri, Alessandro, and Nicola Persico. 2004. "Why Did the Elites Extend the Suffrage? Democracy and the Scope of Government, with an Application to Britain's 'Age of Reform'." Quarterly Journal of Economics, 119:2, pp. 707-65.

[51] Majumdar, Sumon, Anandi Mani, and Sharun W. Mukand. 2004. "Politics, Information, and the Urban Bias." Journal of Development Economics, 75, pp. 137-65.

[52] Mani, Anandi, and Sharun Mukand. 2006. "Democracy, Visibility and Public Good Provision." Journal of Development Economics, forthcoming.

[53] Miguel, Edward, and Michael Kremer. 2004. "Worms: Education and Health Externalities in Kenya." Econometrica, 72:1, pp. 159-217.

[54] Mulligan, Casey B., Ricard Gil, and Xavier Sala-i-Martin. 2004. "Do Democracies Have Different Public Policies than Nondemocracies?" Journal of Economic Perspectives, 18:1, pp. 51-74. 
[55] Murray, Christopher J. L., and Alan D. Lopez. (eds.) 1996. The Global Burden of Disease: A comprehensive assessment of mortality and disability from diseases, injuries, and risk factors in 1990 and projected to 2020. (Cambridge, MA: Harvard University Press).

[56] Nohlen, Dieter, Michael Krennerich, and Bernhard Thibaut. (eds.) 1999. Elections in Africa: A Data Handbook. (Oxford: Oxford University Press).

[57] North, Douglass C., and Barry R. Weingast. 1989. "Constitutions and Commitment: The Evolution of Institutions Governing Public Choice in Seventeenth-century England." Journal of Economic History, 49:4, pp. 803-832.

[58] ORC Macro. 2006. "MEASURE DHS: Model Questionnaire with Commentary for Countries with the Expanded HIV Questions." MEASURE DHS Basic Documentation Number 2.

[59] Pande, Rohini. 2003. "Can Mandated Political Representation Increase Policy Influence for Disadvantaged Minorities? Theory and Evidence from India." American Economic Review, 93:4, pp. 1132-51.

[60] Papaioannou, Elias, and Gregorios Siourounis. 2004. "Democratization and Growth." Unpublished Paper.

[61] Persson, Torsten, and Guido Tabellini. 2006. "Democracy and Development: The Devil in the Details." American Economic Review, 97:2, pp. 319-324.

[62] Pison, Gilles. 1992. "Twins in Sub-Saharan Africa: Frequency, Social Status, and Mortality." in Etienne van de Walle, Gilles Pison, and Mpembele Sala-Diakanda. (eds.) Mortality and Society in Sub-Saharan Africa. (Oxford: Clarendon Press), pp. 253-278.

[63] Pitt, Mark M. 1997. "Estimating the Determinants of Child Health When Fertility and Mortality Are Selective." Journal of Human Resources, 32:1, pp. 129-58.

[64] Przeworski, Adam, Michael E. Alvarez, Jose Antonio Cheibub, and Fernando Limongi. 2000. Democracy and Development: Political Institutions and Well-Being in the World, 1950-1990. (Cambridge, England: Cambridge University Press). 
[65] Przeworski, Adam and Fernando Limongi. 1993. "Political Regimes and Economic Growth." Journal of Economic Perspectives, 7:3, pp. 51-69.

[66] Razzaque, Abdur, Nurul Alam, Lokky Wai, and Andrew Foster. 1990. "Sustained Effects of the 1974-5 Famine on Infant and Child Mortality in a Rural Bangladesh." Population Studies, 44, pp. 145-54.

[67] Rodrik, Dani. 1999. "Democracies Pay Higher Wages." Quarterly Journal of Economics, 114:3, pp. 707-38.

[68] Rodrik, Dani and Romain Wacziarg. 2005. "Do Democratic Transitions Produce Bad Economic Outcomes?" American Economic Review, 95:2, pp. 50-55.

[69] Ross, Michael. 2006. "Is Democracy Good for the Poor?" American Journal of Politica Science, 50:4, pp. 860-74.

[70] Stasavage, David. 2005. "Democracy and Primary School Attendance: Aggregate and Individual Level Evidence from Africa." Unpublished Paper.

[71] Strauss, John, and Duncan Thomas. 1996. "Human Resources: Empirical Modeling of Household and Family Decisions." in J. Behrman and T. N. Srinivasan. (eds.) Handbook of Development Economics, Volume 3A. (Amsterdam: Elsevier). pp. 1883-2023.

[72] UNICEF. 2006. "Childinfo.org: Delivery Care." www.childinfo.org/areas/deliverycare (accessed on 20th August 2006).

[73] van de Walle, Nicolas. 2002. "Africa's Range of Regimes." Journal of Democracy, 13:2, pp. 66-80.

[74] van de Walle, Nicolas. 2003. "Presidentialism and Clientelism in Africa's Emerging Party Systems." Journal of Modern African Studies, 41:2, pp. 297-321.

[75] WHO Collaborative Study Team. 2000. "Effect of Breastfeeding on Infant and Child Mortality due to Infectious Diseases in Less Developed Countries: A Pooled Analysis." Lancet, 355, pp. 451-55.

[76] Wolfers, Justin. 2006. "Did Unilateral Divorce Laws Raise Divorce Rates? A Reconciliation and New Results." American Economic Review, forthcoming. 
[77] World Bank. 2003. World Development Report 2004: Making Services Work for Poor People Washington, D.C.; World Bank and Oxford University Press.

[78] Young, Alwyn. 2005. "In Sorrow to Bring Forth Children: Fertility amidst the Plague of HIV." Unpublished Paper.

[79] Zenger, Elizabeth. 1993. "Siblings' Neonatal Mortality Risks and Birth Spacing in Bangladesh." Demography, 30:3, pp. 477-88. 


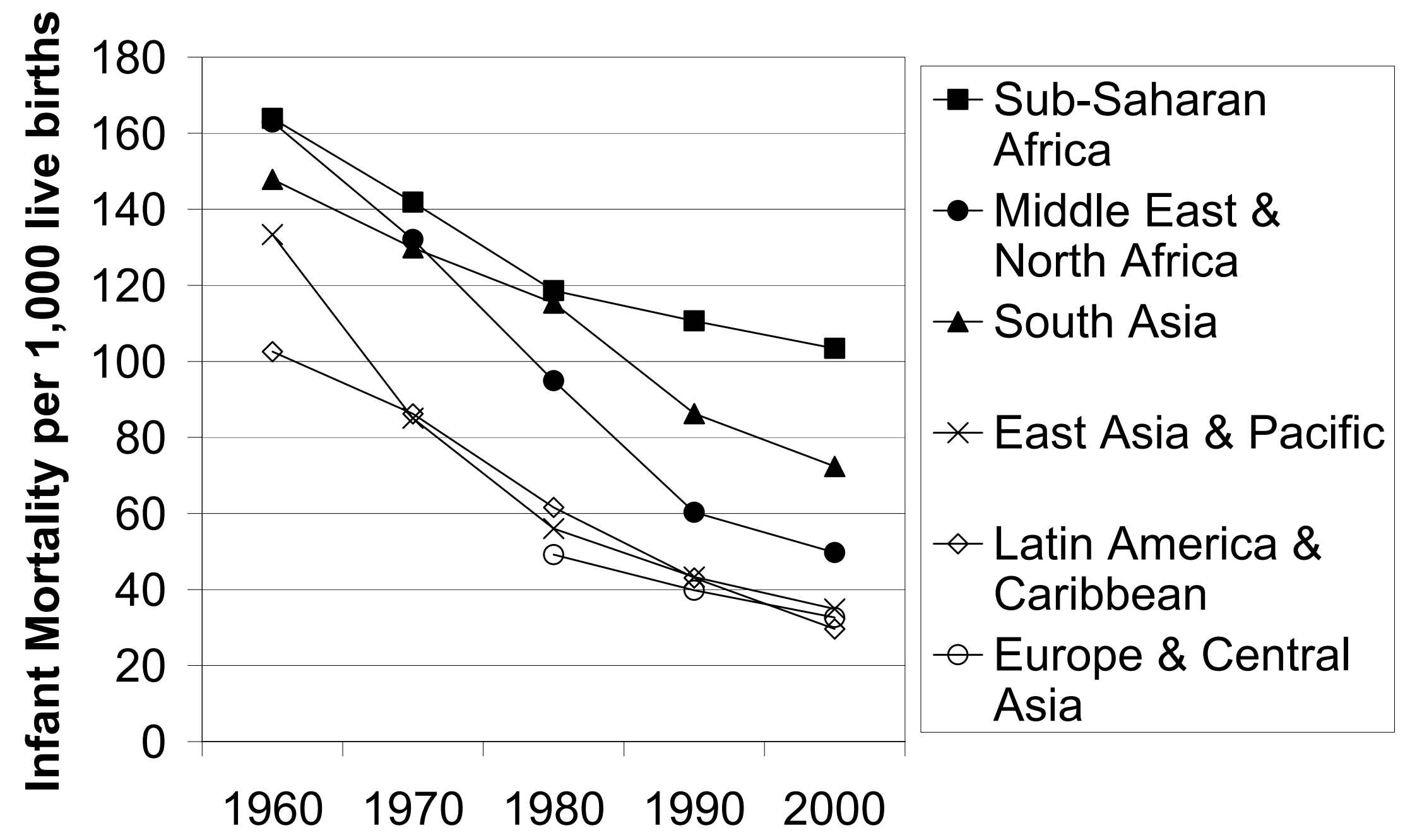

Figure 1: Infant Mortality by Developing Region, 1960-2000 Source: World Development Indicators, April 2006.

Notes: The definition of regions follows the World Bank's classification. 
1990: Comoros

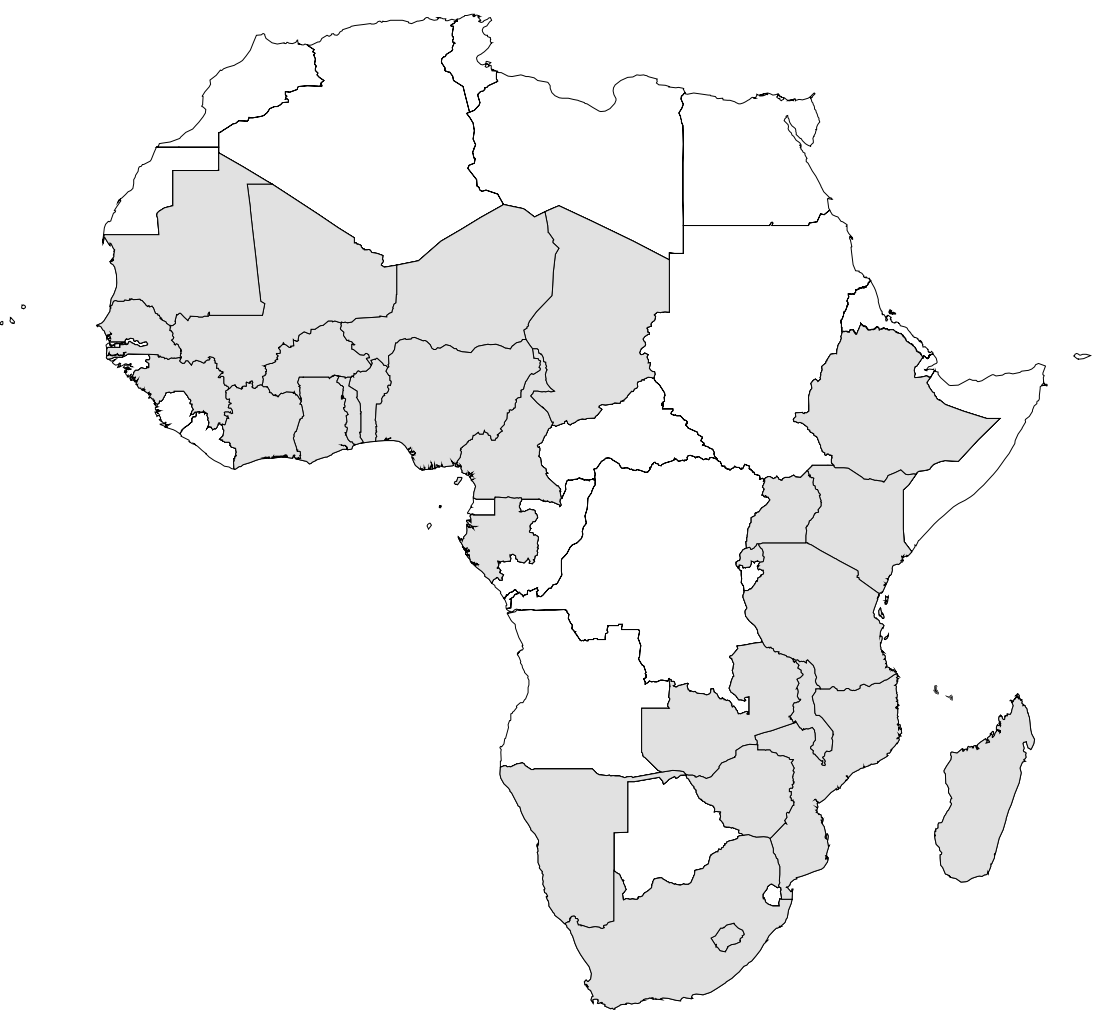

1991: Benin and Zambia

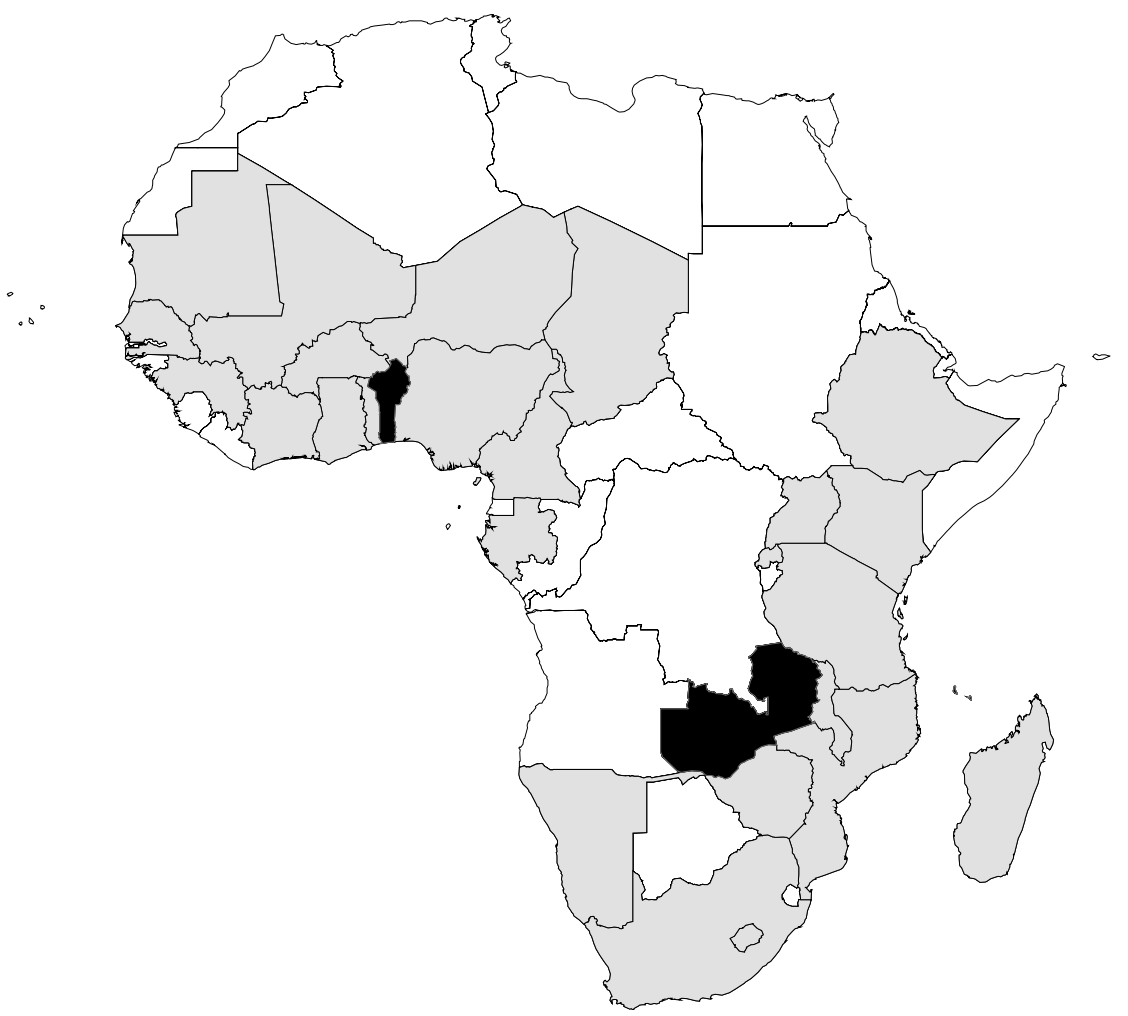

Figure 2: Democratization in the Sample Countries over Time 
1992: Mali

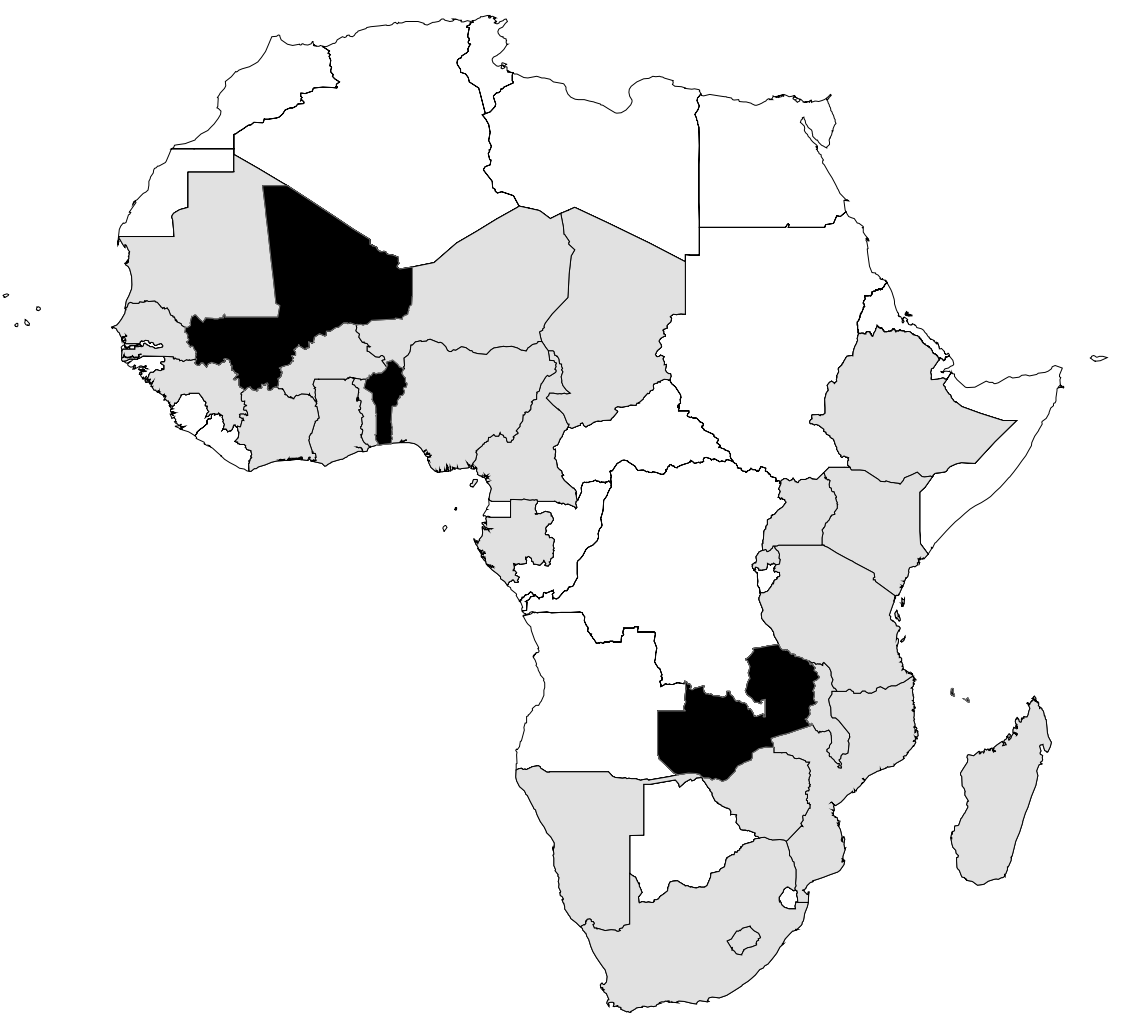

1993: Lesotho, Madagascar, and Niger

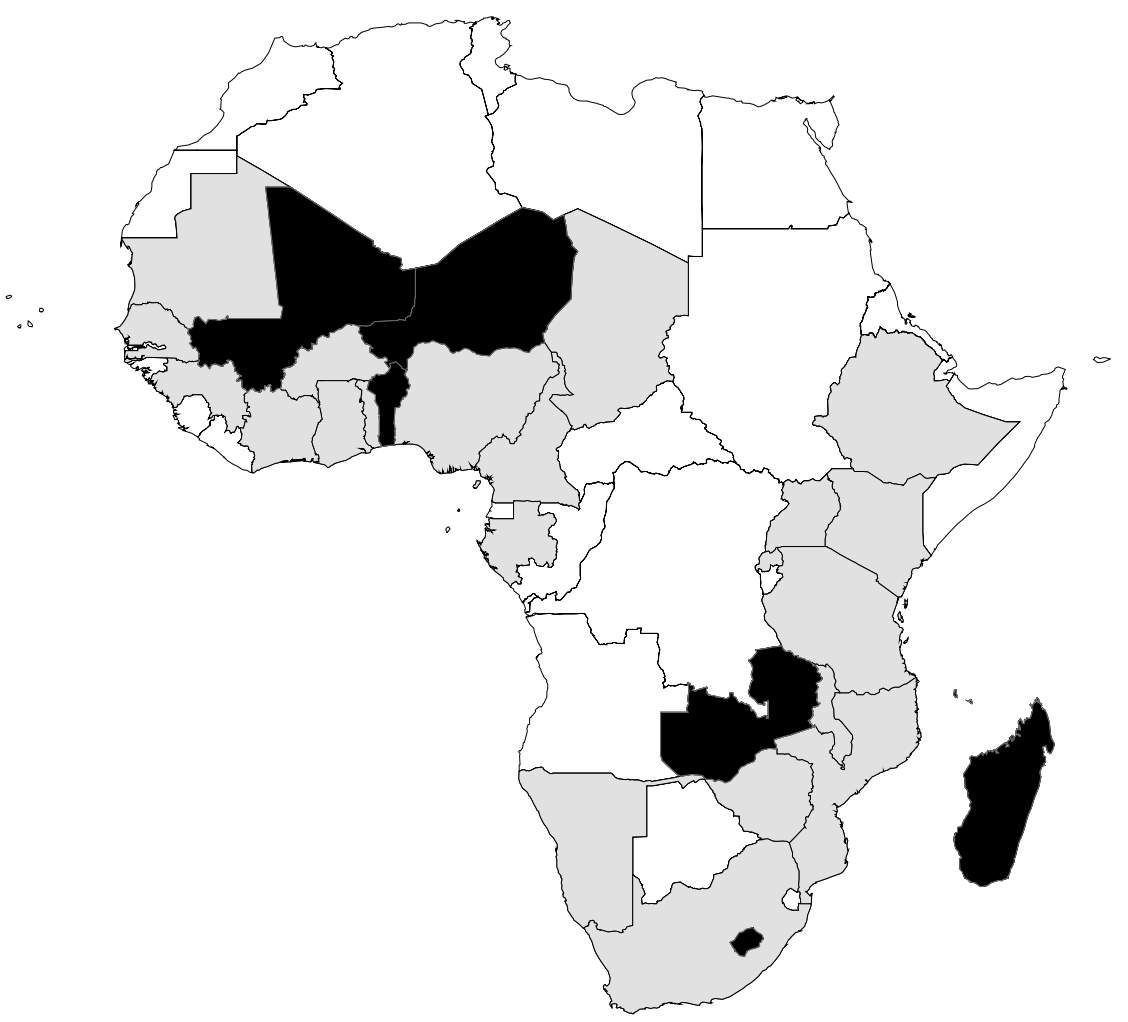

Figure 2 (continued): Democratization in the Sample Countries over Time 
1994: Malawi and South Africa

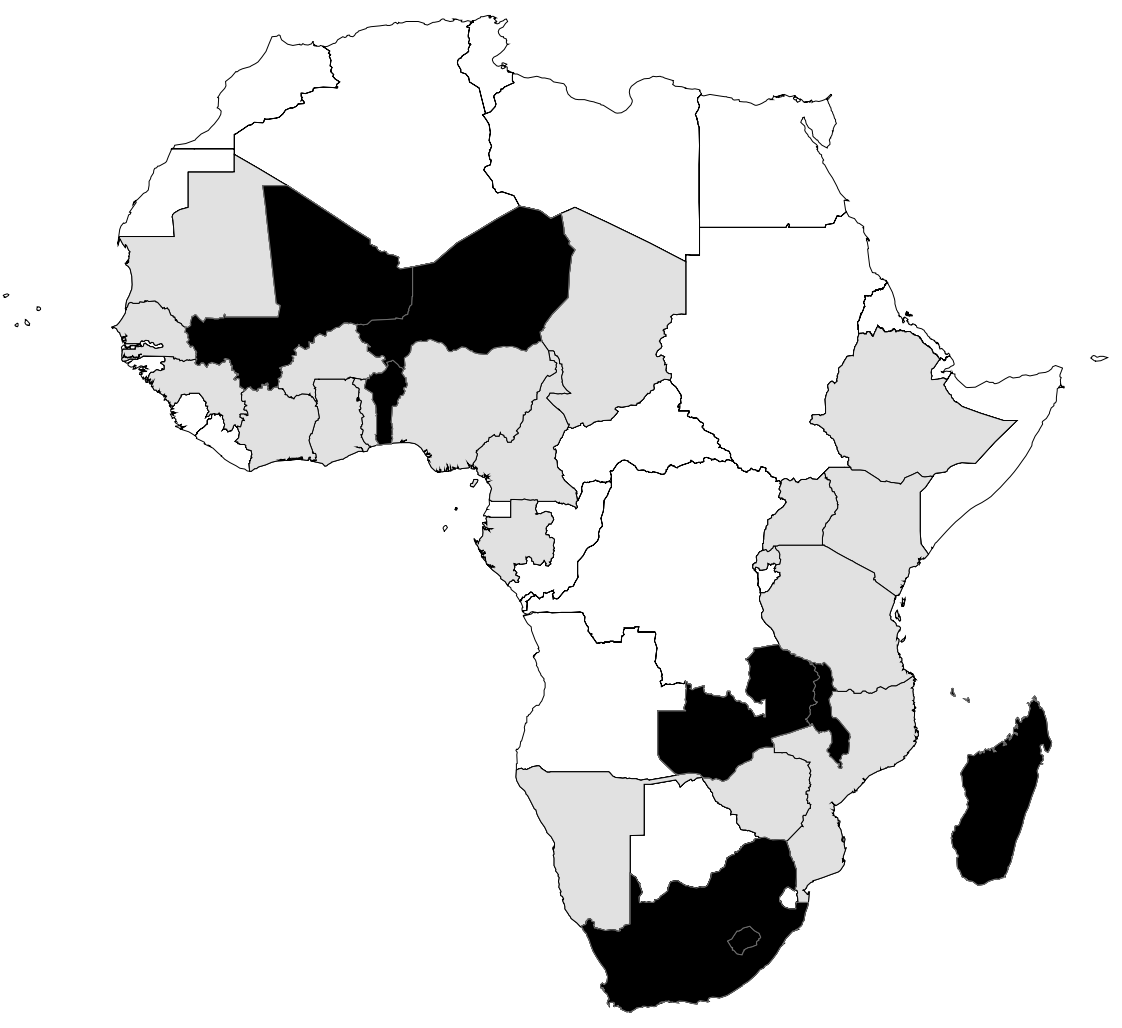

1995: Ethiopia

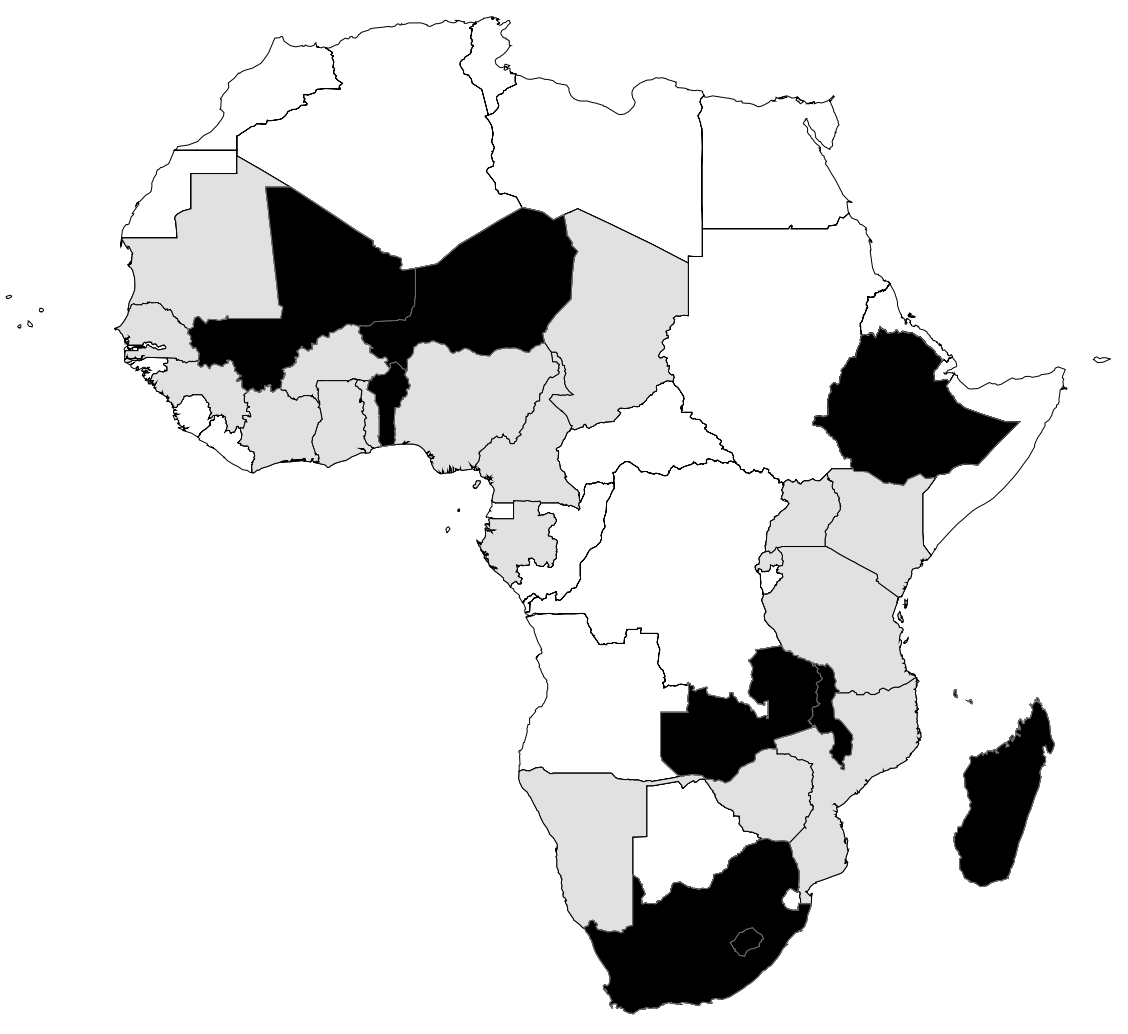

Figure 2 (continued): Democratization in the Sample Countries over Time 


\section{9: Nigeria}

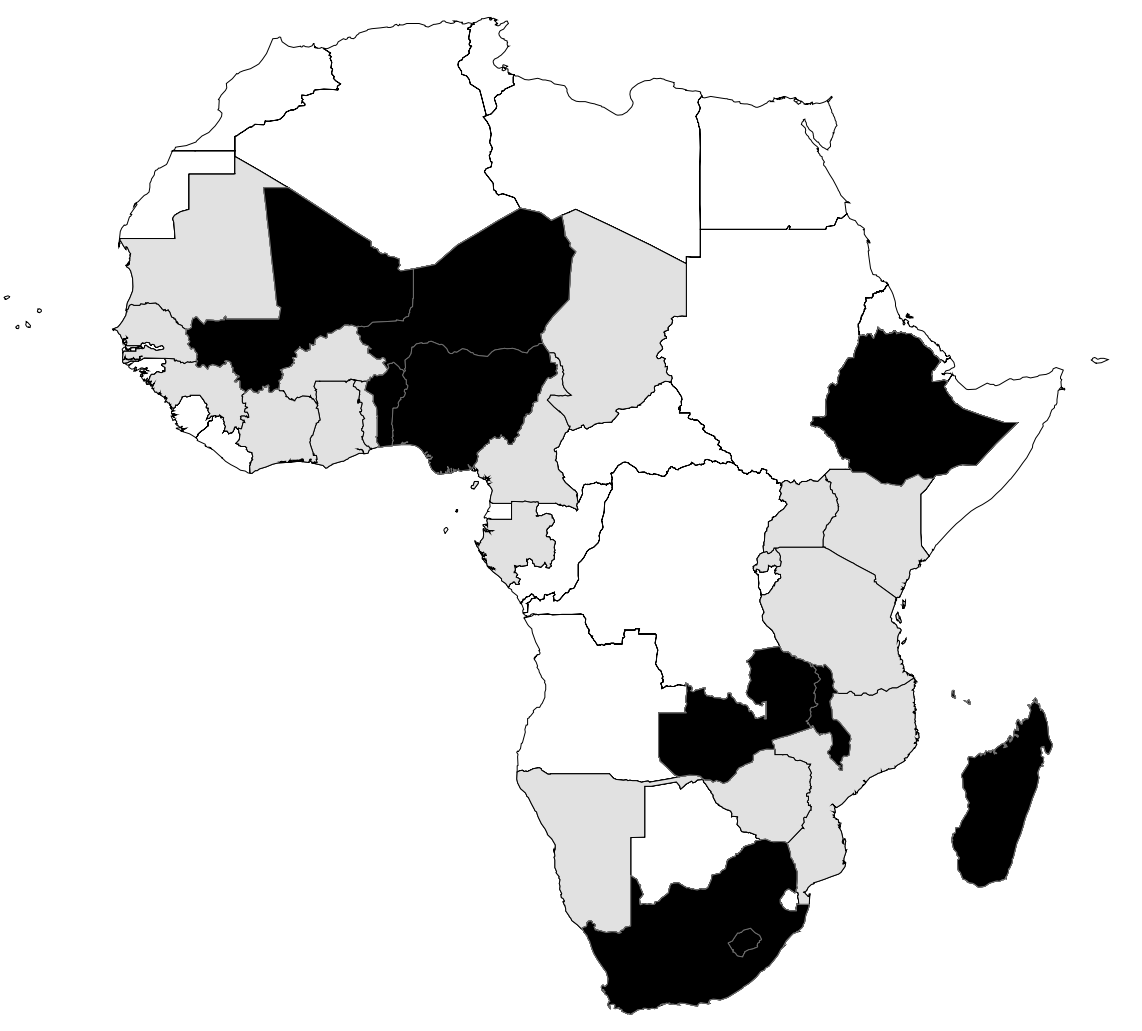

Figure 2 (continued): Democratization in the Sample Countries over Time

Notes: Grey-colored countries are the sample countries; Black-colored democratized. In 1990, Comoros was democratized but due to its small area size it is not visible. 


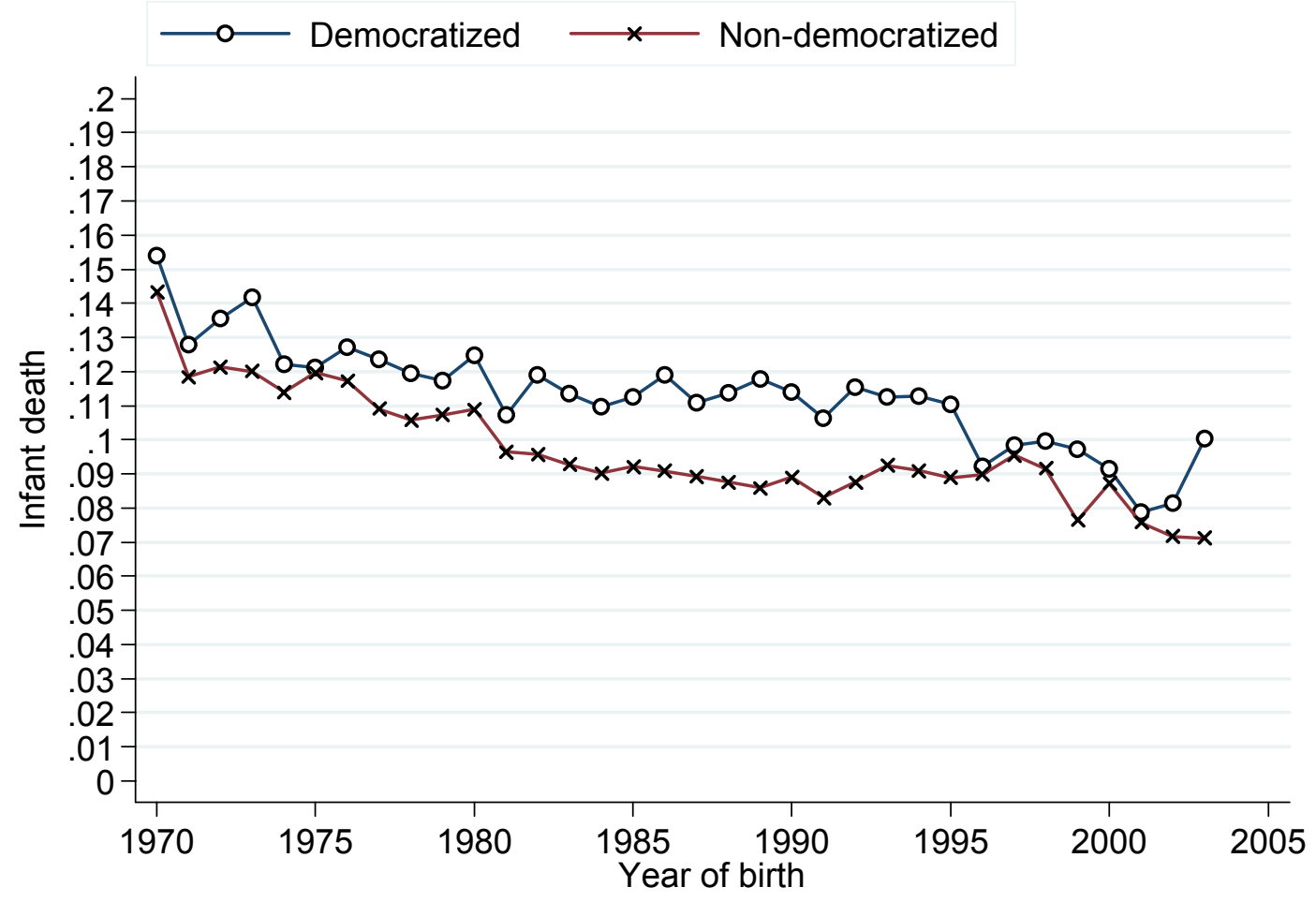

Figure 3: Sample mean infant mortality rates by year for democratized and nondemocratized countries

Notes: Plotted are sample mean infant mortality rates by year for democratized and nondemocratized countries. Year 1970 includes children born in the 1960s; year 2003 includes children born in 2004. See Table 1 for the list of democratized and non-democratized countries. 

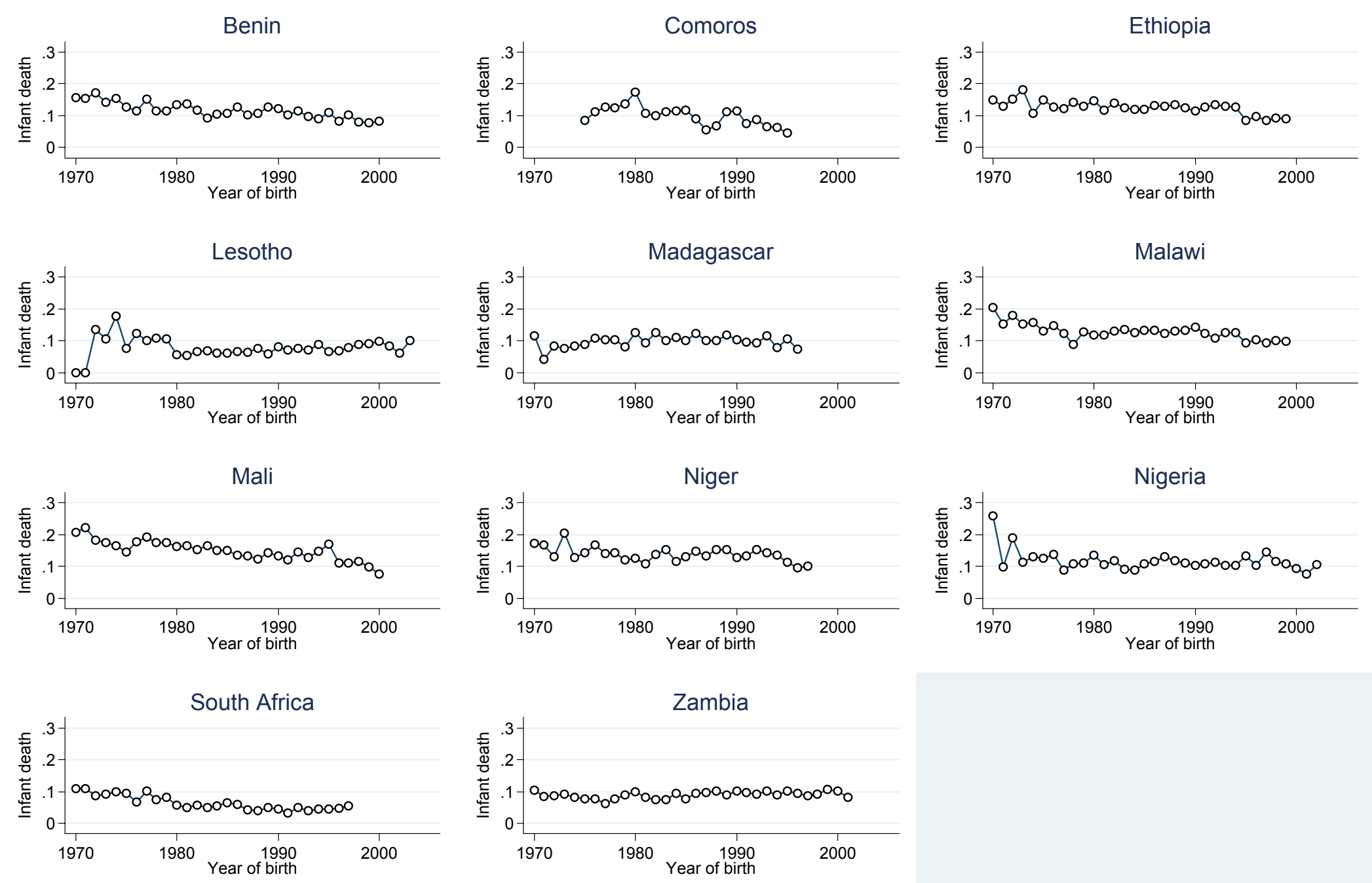

Figure 4: Sample Mean Infant Mortality Rates Over Time by Country for Democratized Countries

Notes: Plotted are sample mean infant mortality rates by year for each of the 11 democratized countries. Year 1970 includes children born in the 1960 s; year 2003 includes children born in 2004. 


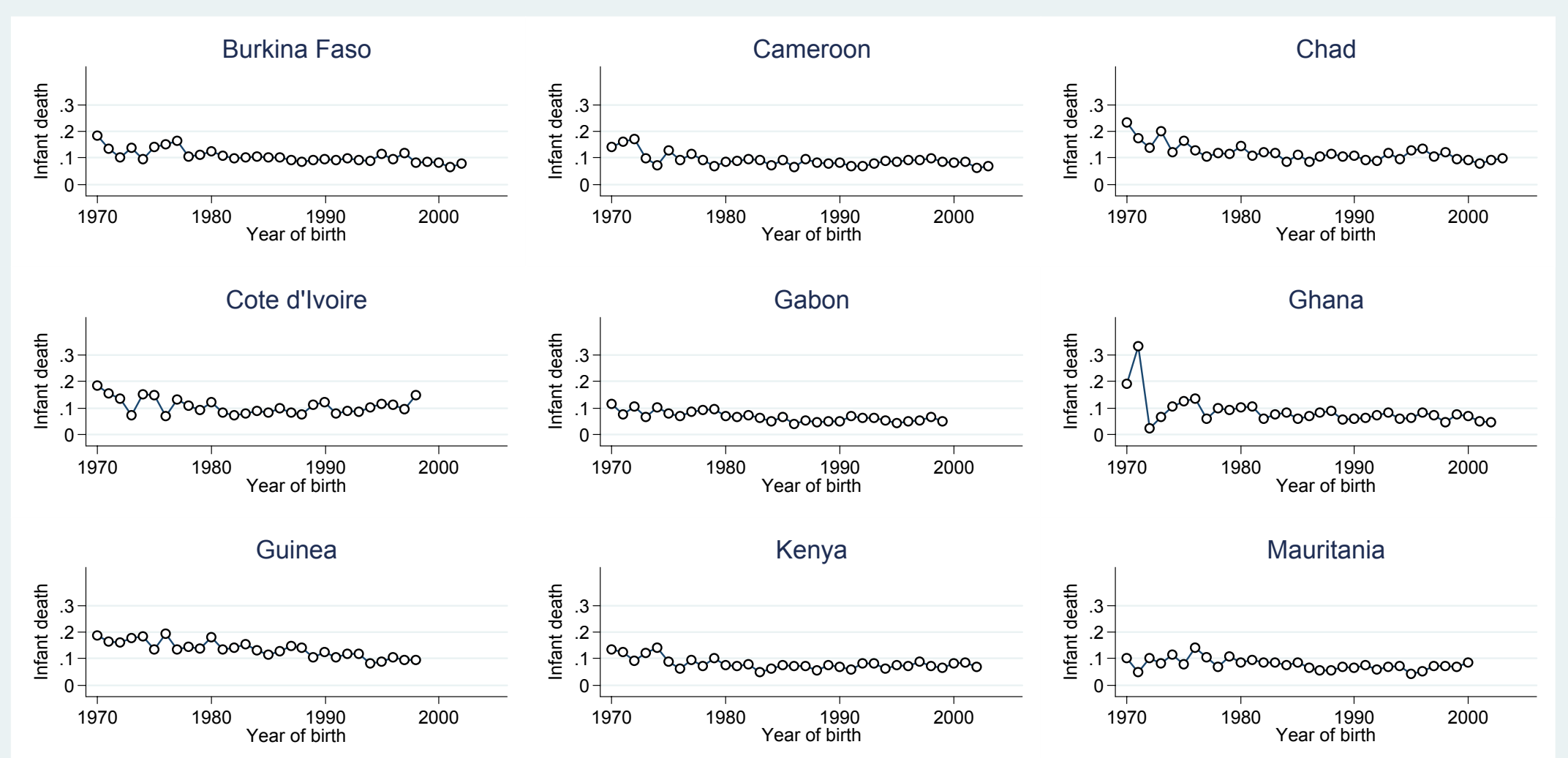

Figure 5: Sample Mean Infant Mortality Rates over Time by Country for Non-democratized Countries

(Continued) 

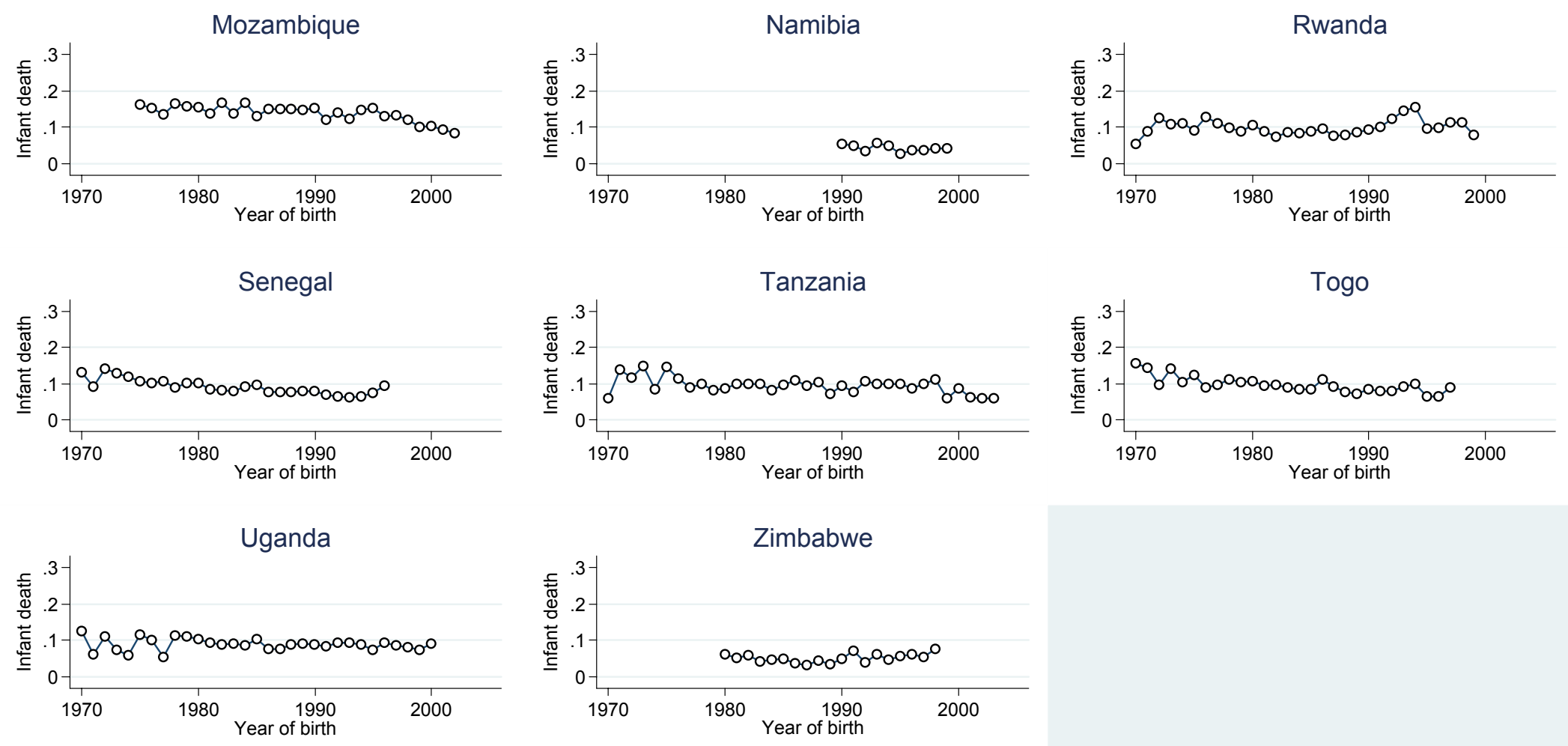

Figure 5 (continued): Sample Mean Infant Mortality Rates Over Time by Country for Non-democratized Countries

Notes: Plotted are sample mean infant mortality rates by year for each of the 17 non-democratized countries. Year 1970 includes children born in the 1960 s; year 2003 includes children born in 2004. 


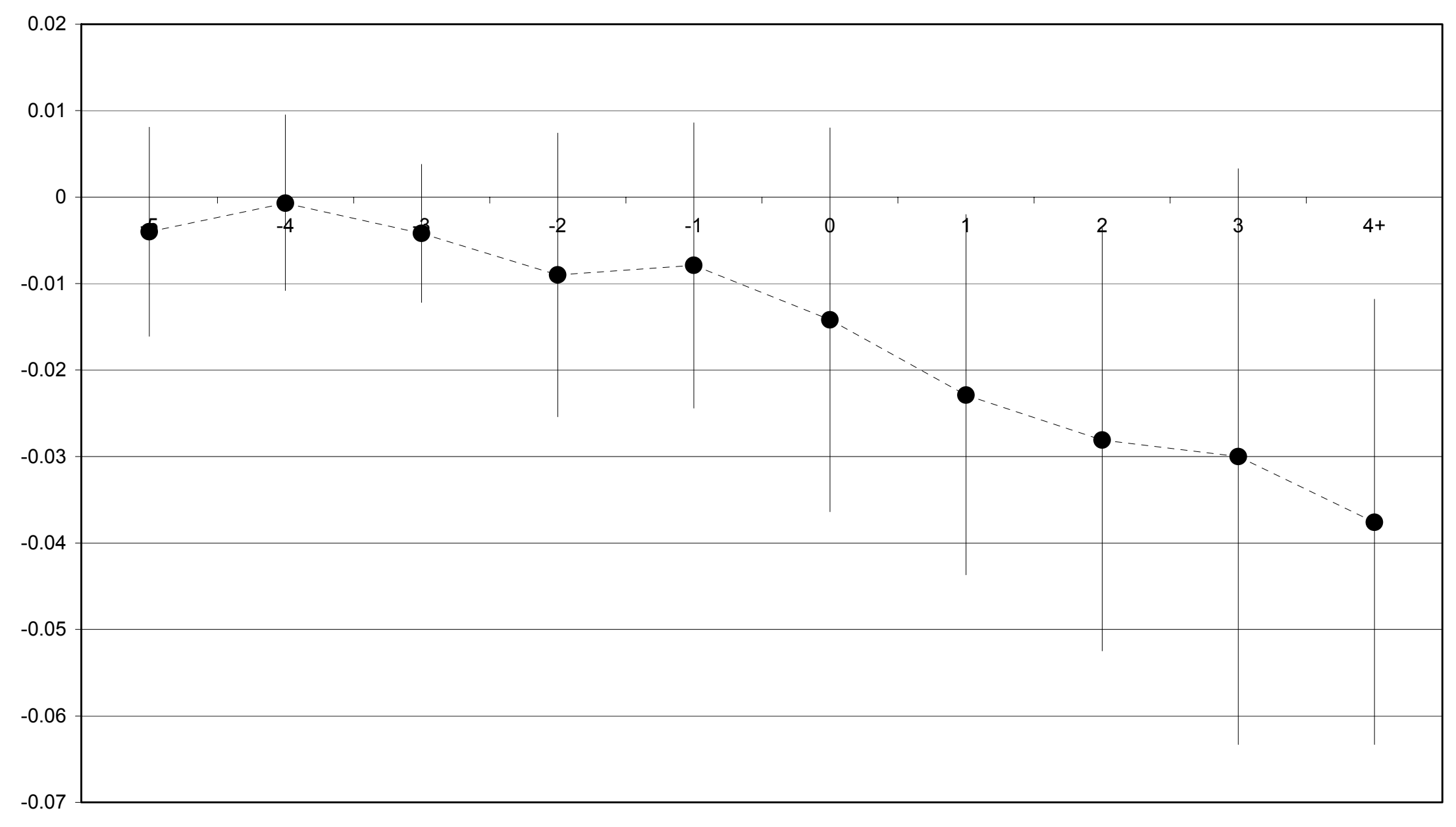

Number of Years Since Democratization

Figure 6: Dynamics of Infant Mortality Before and After Democratization

Notes: Plotted are estimated coefficients reported in Appendix Table A3. Vertical bands represent 95 percent level confidence intervals of the estimated coefficients. 
Table 1: Years of Democratization by Different Measures of Democracy and the Sample Period for 28 African Countries

\begin{tabular}{|c|c|c|c|c|c|c|c|c|c|}
\hline Country & $\begin{array}{c}\text { (1) } \\
\text { Multiparty }\end{array}$ & $\begin{array}{c}(2) \\
\mathrm{PR}<3\end{array}$ & $\begin{array}{c}(3) \\
\mathrm{PR}<4 \\
\end{array}$ & $\begin{array}{c}(4) \\
\mathrm{PR}<5 \\
\end{array}$ & $\begin{array}{c}(5) \\
\text { POLITY2>6 }\end{array}$ & $\begin{array}{c}(6) \\
\text { POLITY2>4 }\end{array}$ & $\begin{array}{c}(7) \\
\text { POLITY2>0 }\end{array}$ & EXREC $>=7$ \& PARCOMP $>=3$ & $\begin{array}{c}(9) \\
\text { Sample Period }\end{array}$ \\
\hline \multicolumn{10}{|c|}{ Democratized Countries } \\
\hline Benin & 1991 & 1991 & 1991 & 1991 & & 1991 & 1991 & 1991 & $1964-2000$ \\
\hline Comoros & 1990 & & & 1991 & & & 1990 & 1990 & 1975-1995 \\
\hline Ethiopia & 1995 & & & 1995 & & & 1993 & 1995 & 1963-1999 \\
\hline Lesotho & 1993 & 2002 & *1993 & 1993 & *1993 & *1993 & *1993 & *1993 & $1967,69-2004$ \\
\hline Madagascar & 1993 & 1993 & 1993 & 1990 & 1992 & 1992 & 1991 & 1992 & 1962-1996 \\
\hline Malawi & 1994 & 1994 & 1994 & 1994 & 1994 & 1994 & 1994 & 1994 & 1964-1999 \\
\hline Mali & 1992 & *1992 & 1992 & 1992 & *1992 & 1992 & 1992 & 1992 & $1964-2000$ \\
\hline Niger & 1993 & & *1993 & *1993 & *1992 & *1992 & *1991 & *1992 & $1960-1997$ \\
\hline Nigeria & 1999 & & & 1999 & & & 1999 & & $1965-2002$ \\
\hline South Africa & 1994 & 1994 & 1994 & 1994 & 1993 & 1990 & - & 1994 & $1961-1997$ \\
\hline Zambia & 1991 & *1991 & *1991 & *1991 & & *1991 & 1991 & *1991 & $1965-2001$ \\
\hline \multicolumn{10}{|c|}{ Non-democratized Countries } \\
\hline Burkina Faso & 1991 & & & 1999 & & & & & 1966-2002 \\
\hline Cameroon & 1992 & & & & & & & & $1968-2003$ \\
\hline Chad & 1996 & & & & & & & & $1962,65,67-2003$ \\
\hline Cote d'Ivoire & 1990 & & & & & & & & $1962-1998$ \\
\hline Gabon & 1993 & & & *1990 & & & & & $1962-1999$ \\
\hline Ghana & 1992 & 2000 & 1996 & 1995 & & 2001 & 1996 & 2001 & $1967-2002$ \\
\hline Guinea & 1993 & & & & & & & & $1961-1998$ \\
\hline Kenya & 1992 & & & *1992 & 2002 & 2002 & 2002 & 2002 & $1965-2002$ \\
\hline Mauritania & 1992 & & & & & & & & $1962-2000$ \\
\hline Mozambique & 1994 & & 1994 & 1994 & & 1994 & 1994 & 1994 & $1975-2002$ \\
\hline Namibia & - & - & - & - & - & - & - & - & 1990-1999 \\
\hline Rwanda & (2003) & & & & & & & & 1963-1999 \\
\hline Senegal & 1978 & (2002) & *1984 & 1978 & $(2000)$ & $(2000)$ & (2000) & & 1961-1996 \\
\hline Tanzania & 1995 & & & 1999 & & & 2000 & 2000 & 1968-2004 \\
\hline Togo & 1993 & & & & & & & & $1960-1997$ \\
\hline Uganda & 1996 & & & *1997 & & & & & $1964-2000$ \\
\hline Zimbabwe & - & & & & & & & & $1980-1998$ \\
\hline
\end{tabular}

Notes: Column (1) lists the year of the first multiparty elections for executive office. "-" indicates that the country is democratic for all years in the sample. Years in parentheses are the years of democratization outside the sample period. The blank cells indicate that the country is never democratic during the sample period.

* Democracy collapses within the sample period. 
Table 2: Summary Statistics

\begin{tabular}{|c|c|c|c|c|}
\hline \multirow{3}{*}{ Countries: } & \multirow{3}{*}{$\begin{array}{l}\text { (1) } \\
\text { All }\end{array}$} & (2) & (3) & \multirow{3}{*}{$\begin{array}{c}(4) \\
\text { Non-democratized }\end{array}$} \\
\hline & & \multicolumn{2}{|c|}{ Democratized } & \\
\hline & & Before & After & \\
\hline \multicolumn{5}{|l|}{ Baby-level Variables } \\
\hline \multicolumn{5}{|l|}{ Infant death } \\
\hline \multirow[t]{2}{*}{ (All) } & 0.100 & 0.116 & 0.100 & 0.091 \\
\hline & 643846 & 197891 & 79805 & 366150 \\
\hline \multirow[t]{2}{*}{ (Educated) } & 0.080 & 0.086 & 0.086 & 0.076 \\
\hline & 287387 & 81284 & 37267 & 168836 \\
\hline \multirow[t]{2}{*}{ (Uneducated) } & 0.116 & 0.138 & 0.111 & 0.104 \\
\hline & 356450 & 116600 & 42538 & 197312 \\
\hline \multirow[t]{2}{*}{ (Dictator's ethnicity) } & $N / A$ & 0.121 & 0.112 & N/A \\
\hline & & 37800 & 18365 & \\
\hline \multirow{2}{*}{ (Other ethnicity) } & N/A & 0.124 & 0.100 & N/A \\
\hline & & 89028 & 37987 & \\
\hline \multicolumn{5}{|l|}{ Neonatal death } \\
\hline \multirow[t]{2}{*}{ (All) } & 0.047 & 0.054 & 0.046 & 0.043 \\
\hline & 643846 & 197891 & 79805 & 366150 \\
\hline \multirow[t]{2}{*}{ (Educated) } & 0.036 & 0.038 & 0.039 & 0.035 \\
\hline & 287387 & 81284 & 37267 & 168836 \\
\hline \multirow[t]{2}{*}{ (Uneducated) } & 0.055 & 0.065 & 0.053 & 0.049 \\
\hline & 356450 & 116600 & 42538 & 197312 \\
\hline \multirow[t]{2}{*}{ (Dictator's ethnicity) } & N/A & 0.121 & 0.112 & $N / A$ \\
\hline & & 37800 & 18365 & \\
\hline \multirow[t]{2}{*}{ (Other ethnicity) } & $\mathrm{N} / \mathrm{A}$ & 0.124 & 0.100 & N/A \\
\hline & & 89028 & 37987 & \\
\hline \multirow[t]{2}{*}{ Girl } & 0.491 & 0.487 & 0.494 & 0.492 \\
\hline & 643846 & 197891 & 79805 & 366150 \\
\hline \multirow[t]{2}{*}{ Multiple birth } & 0.032 & 0.029 & 0.037 & 0.032 \\
\hline & 643846 & 197891 & 79805 & 366150 \\
\hline Mother's age at birth & 0.534 & 0.541 & 0.506 & 0.537 \\
\hline $20-29$ & 643846 & 197891 & 79805 & 366150 \\
\hline Mother's age at birth & 0.200 & 0.168 & 0.261 & 0.203 \\
\hline $30-39$ & 643846 & 197891 & 79805 & 366150 \\
\hline Mother's age at birth & 0.018 & 0.008 & 0.040 & 0.018 \\
\hline $40-49$ & 643846 & 197891 & 79805 & 366150 \\
\hline \multirow[t]{2}{*}{ Short birth spacing } & 0.292 & 0.333 & 0.237 & 0.282 \\
\hline & 483880 & 146213 & 62589 & 275078 \\
\hline \multicolumn{5}{|l|}{ Mother-level Variable } \\
\hline \multirow[t]{3}{*}{ Number of births } & 4.028 & \multirow{2}{*}{\multicolumn{2}{|c|}{$\begin{array}{c}4.059 \\
(2754)\end{array}$}} & 4.005 \\
\hline & $(2.686)$ & & & (2.634) \\
\hline & 161876 & \multicolumn{2}{|c|}{68602} & 93274 \\
\hline
\end{tabular}

Notes: In each cell, the sample mean is reported at the top row; the number of observations at the bottom row. For number of births, which refers to the birth order of the youngest child in the sample, standard deviations are reported in parentheses at the middle row. Column (2) reports means for children born in democratized countries until the year of democratization; Column (3) for children born in democratized countries after the year of democratization; Column (4) for children born in non-democratized countries. 
Table 3: Infant Mortality Drops After Democratization

\begin{tabular}{lcccccc}
\hline & $(1)$ & $(2)$ & $(3)$ & $(4)$ & $(5)$ & $(6)$ \\
\hline Dependent Variable: & Infant & Infant & Infant & Infant & Infant & Neonatal \\
& Death & Death & Death & Death & Death & Death \\
Democratization & 0.009 & $-0.011^{*}$ & $-0.017^{* *}$ & $-0.017^{* *}$ & $-0.018^{* *}$ & $-0.010^{* *}$ \\
& {$[0.008]$} & {$[0.005]$} & {$[0.006]$} & {$[0.006]$} & {$[0.006]$} & {$[0.003]$} \\
Girl & & & & & $-0.014^{* *}$ & $-0.011^{* *}$ \\
& & & & & {$[0.001]$} & {$[0.001]$} \\
Born in a multiple birth & & & & & $0.231^{* *}$ & $0.163^{* *}$ \\
& & & & & {$[0.012]$} & {$[0.009]$} \\
\hline Year fixed effects & YES & YES & YES & YES & YES & YES \\
Country fixed effects & NO & YES & NO & NO & NO & NO \\
Mother fixed effects & NO & NO & YES & YES & YES & YES \\
Country-specific linear trends & NO & NO & NO & YES & YES & YES \\
Number of Countries & 28 & 28 & 28 & 28 & 28 & 28 \\
Number of Mothers & 161876 & 161876 & 161876 & 161876 & 161876 & 161876 \\
Observations & 643846 & 643846 & 643846 & 643846 & 643846 & 643846 \\
Adjusted R-squared & 0.001 & 0.008 & 0.060 & 0.061 & 0.077 & 0.080 \\
\hline Notes: Sandard
\end{tabular}

Notes: Standard errors clustered at the country level are reported in brackets. Infant death is death before turning the age of 1 year; neonatal death is death before turning the age of 1 month. Adjusted $\mathrm{R}$-squared refers to variation explained by all regressors including any fixed effects.

* significant at $5 \%$; ** significant at $1 \%$. 
Table 4: Impact of Democratization by Mother's Education and Ethnicity

\begin{tabular}{|c|c|c|c|c|c|c|}
\hline & (1) & (2) & (3) & $(4)$ & (5) & (6) \\
\hline Dependent variable: & $\begin{array}{l}\text { Infant } \\
\text { Death }\end{array}$ & $\begin{array}{l}\text { Neonatal } \\
\text { Death }\end{array}$ & $\begin{array}{l}\text { Infant } \\
\text { Death }\end{array}$ & $\begin{array}{l}\text { Neonatal } \\
\text { Death }\end{array}$ & $\begin{array}{l}\text { Infant } \\
\text { Death }\end{array}$ & $\begin{array}{c}\text { Neonatal } \\
\text { Death }\end{array}$ \\
\hline \multicolumn{7}{|l|}{ Democratization interacted with } \\
\hline Educated & $\begin{array}{c}-0.009 \\
{[0.006]}\end{array}$ & $\begin{array}{c}-0.006 \\
{[0.003]}\end{array}$ & & & & \\
\hline Uneducated & $\begin{array}{c}-0.023^{* *} \\
{[0.007]}\end{array}$ & $\begin{array}{c}-0.012^{* *} \\
{[0.003]}\end{array}$ & & & & \\
\hline Educated \& Urban & & & $\begin{array}{l}-0.005 \\
{[0.007]}\end{array}$ & $\begin{array}{l}-0.004 \\
{[0.005]}\end{array}$ & & \\
\hline Educated \& Rural & & & $\begin{array}{l}-0.011 \\
{[0.007]}\end{array}$ & $\begin{array}{l}-0.006 \\
{[0.004]}\end{array}$ & & \\
\hline Uneducated \& Urban & & & $\begin{array}{l}-0.018 \\
{[0.012]}\end{array}$ & $\begin{array}{l}-0.004 \\
{[0.009]}\end{array}$ & & \\
\hline Uneducated \& Rural & & & $\begin{array}{l}-0.024^{* *} \\
{[0.007]}\end{array}$ & $\begin{array}{c}-0.014^{* *} \\
{[0.003]}\end{array}$ & & \\
\hline Dictator's ethnic group & & & & & $\begin{array}{l}-0.008 \\
{[0.008]}\end{array}$ & $\begin{array}{l}-0.004 \\
{[0.005]}\end{array}$ \\
\hline Other ethnic groups & & & & & $\begin{array}{l}-0.017^{\star} \\
{[0.006]}\end{array}$ & $\begin{array}{c}-0.012^{* *} \\
{[0.004]}\end{array}$ \\
\hline F-test & 7.94 & 8.46 & 0.78 & 0.81 & 17.16 & 6.79 \\
\hline$p$-value & 0.009 & 0.007 & 0.469 & 0.454 & 0.001 & 0.018 \\
\hline Girl dummy & YES & YES & YES & YES & YES & YES \\
\hline Multiple birth dummy & YES & YES & YES & YES & YES & YES \\
\hline Mother fixed effects & YES & YES & YES & YES & YES & YES \\
\hline Year fixed effects & YES & YES & YES & YES & YES & YES \\
\hline Country-specific linear trends & YES & YES & YES & YES & YES & YES \\
\hline Number of Countries & 28 & 28 & 28 & 28 & 19 & 19 \\
\hline Number of Mothers & 161873 & 161873 & 161873 & 161873 & 114324 & 114324 \\
\hline Observations & 643837 & 643837 & 643837 & 643837 & 460952 & 460952 \\
\hline Adjusted R-squared & 0.077 & 0.080 & 0.309 & 0.311 & 0.074 & 0.077 \\
\hline
\end{tabular}

Notes: Standard errors clustered at the country level are reported in brackets. Infant death (the dependent variables in odd-numbered columns) is death before turning the age of 1 year. Neonatal death (the dependent variables in even-numbered columns) is death before turning the age of 1 month. Adjusted R-squared refers to variation explained by all the regressors, including any fixed effects. The nulls for F-tests are: for columns (1) and (2), coefficients on the two interaction terms between democratization and mothers' education level are the same; for columns (3) and (4), coefficients on the two interaction terms of democratization and educated mothers with areas of residence are the same and coefficients on the two interaction terms of democratization and uneducated mothers with areas of residence are the same; for columns (5) and (6), coefficients on the two interaction terms between democratization and mothers' ethnicity are the same.

${ }^{*}$ significant at $5 \%$; ${ }^{* *}$ significant at $1 \%$. 
Table 5: Robustness Checks

(The Dependent Variable: Death before turning the age of one year)

\begin{tabular}{|c|c|c|c|c|c|c|c|c|}
\hline & $(1)$ & $(2)$ & $(3)$ & $(4)$ & (5) & (6) & $(7)$ & $(8)$ \\
\hline Sample: & PWT6.2 & $\begin{array}{c}\text { Born to } \\
\text { Poor Mothers }\end{array}$ & $\begin{array}{l}\text { Until } \\
2003\end{array}$ & $\begin{array}{l}\text { Since } \\
1961\end{array}$ & All & All & $\begin{array}{l}\text { All but } \\
\text { First-born }\end{array}$ & $\begin{array}{l}\text { Without } \\
\text { Migration }\end{array}$ \\
\hline Democratization & $\begin{array}{c}-0.017^{* *} \\
{[0.006]}\end{array}$ & $\begin{array}{l}-0.018^{*} \\
{[0.007]}\end{array}$ & $\begin{array}{c}-0.018^{* *} \\
{[0.006]}\end{array}$ & $\begin{array}{l}-0.018^{* *} \\
{[0.006]}\end{array}$ & $\begin{array}{l}-0.018^{* *} \\
{[0.006]}\end{array}$ & $\begin{array}{c}-0.016^{* *} \\
{[0.006]}\end{array}$ & $\begin{array}{l}-0.015^{*} \\
{[0.007]}\end{array}$ & $\begin{array}{l}-0.017^{*} \\
{[0.006]}\end{array}$ \\
\hline Log per capita GDP & $\begin{array}{l}-0.032 \\
{[0.017]}\end{array}$ & & & & & & & \\
\hline Log per capita GDP (1-year lag) & $\begin{array}{c}0.004 \\
{[0.014]}\end{array}$ & & & & & & & \\
\hline War & & & $\begin{array}{c}0.004 \\
{[0.004]}\end{array}$ & & & & & \\
\hline $\begin{array}{l}\text { Foreign Aid } \\
\text { (million US\$, } 2004 \text { prices) }\end{array}$ & & & & $\begin{array}{c}0.000 \\
{[0.000]}\end{array}$ & & & & \\
\hline $\begin{array}{l}\text { Foreign Aid (1-year lag) } \\
\text { (million US\$, } 2004 \text { prices) }\end{array}$ & & & & $\begin{array}{c}0.000 \\
{[0.000]}\end{array}$ & & & & \\
\hline $\begin{array}{l}\text { HIV infection rates } \\
\text { among pregnant women }\end{array}$ & & & & & $\begin{array}{c}0.021 \\
{[0.069]}\end{array}$ & & & \\
\hline $\begin{array}{l}\text { Short birthspacing } \\
\text { (less than } 24 \text { months) }\end{array}$ & & & & & & & $\begin{array}{l}0.039^{* *} \\
{[0.004]}\end{array}$ & \\
\hline Girl dummy & YES & YES & YES & YES & YES & YES & YES & YES \\
\hline Multiple birth dummy & YES & YES & YES & YES & YES & YES & YES & YES \\
\hline Mother fixed effects & YES & YES & YES & YES & YES & YES & YES & YES \\
\hline Year fixed effects & YES & YES & YES & YES & YES & YES & YES & YES \\
\hline Country-specific linear trends & YES & YES & YES & YES & YES & YES & YES & YES \\
\hline Additional Controls & NO & NO & NO & NO & NO & YES & NO & NO \\
\hline Number of Countries & 28 & 28 & 28 & 28 & 28 & 28 & 28 & 25 \\
\hline Number of Mothers & 161858 & 47910 & 161864 & 161876 & 161876 & 161876 & 129343 & 116259 \\
\hline Observations & 643532 & 203027 & 643791 & 643843 & 643846 & 643846 & 483880 & 414767 \\
\hline Adjusted R-squared & 0.077 & 0.091 & 0.077 & 0.077 & 0.077 & 0.079 & 0.072 & 0.067 \\
\hline
\end{tabular}

Notes : Standard errors clustered at the country level are reported in brackets. In columns (1), (3), (4), and (7), some observations are dropped due to the unavailability of control variables. Column (2) restricts the sample to babies born to mothers having no consumer durable good at the survey date; Column (8) drops babies born before one year has passed since their mother migrated to the surveyed community and babies whose mother's information on migration is not available. In Column (6), birth order dummies and mothers' age-at-birth category dummies are additionally controlled for. Adjusted R-squared refers to variation explained by all regressors, including any fixed effects.

* significant at 5 percent; ${ }^{* *}$ at 1 percent. 
Table 6: Robustness to Other Dimensions of Democracy

(The Dependent Variable: Death before turning the age of one year)

\begin{tabular}{|c|c|c|c|c|c|}
\hline & (1) & (2) & (3) & (4) & (5) \\
\hline Democratization & $\begin{array}{c}-0.018^{* *} \\
{[0.006]}\end{array}$ & $\begin{array}{c}-0.018^{* *} \\
{[0.006]}\end{array}$ & $\begin{array}{c}-0.021^{* *} \\
{[0.006]}\end{array}$ & $\begin{array}{c}-0.019^{* \star} \\
{[0.006]}\end{array}$ & $\begin{array}{l}-0.015^{\star} \\
{[0.007]}\end{array}$ \\
\hline Multiparty Elections & $\begin{array}{c}-0.002 \\
{[0.004]}\end{array}$ & & & & \\
\hline Leadership Change & & $\begin{array}{c}-0.002 \\
{[0.006]}\end{array}$ & & & \\
\hline Executive Constraints & & & $\begin{array}{c}0.002 \\
{[0.001]}\end{array}$ & & \\
\hline Civil Liberty Restriction & & & & $\begin{array}{l}-0.001 \\
{[0.001]}\end{array}$ & \\
\hline Free Press & & & & & $\begin{array}{l}-0.005 \\
{[0.009]}\end{array}$ \\
\hline Partly Free Press & & & & & $\begin{array}{c}0.000 \\
{[0.003]}\end{array}$ \\
\hline $\begin{array}{l}\text { F-test } \\
p \text {-value }\end{array}$ & $\begin{array}{c}5.76 \\
0.024\end{array}$ & $\begin{array}{c}3.85 \\
0.060\end{array}$ & & & \\
\hline Girl dummy & YES & YES & $\overline{\text { YES }}$ & $\overline{\text { YES }}$ & $\overline{\text { YES }}$ \\
\hline Multiple birth dummy & YES & YES & YES & YES & YES \\
\hline Mother fixed effects & YES & YES & YES & YES & YES \\
\hline Year fixed effects & YES & YES & YES & YES & YES \\
\hline Country-specific linear trends & YES & YES & YES & YES & YES \\
\hline Number of Countries & 28 & 28 & 28 & 28 & 28 \\
\hline Number of Mothers & 161876 & 161876 & 160184 & 161629 & 157709 \\
\hline Observations & 643846 & 643846 & 611866 & 634011 & 552397 \\
\hline Adjusted R-squared & 0.077 & 0.077 & 0.076 & 0.077 & 0.076 \\
\hline
\end{tabular}

Notes: Standard errors clustered at the country level are reported in brackets. Adjusted $\mathrm{R}$-squared refers to variation explained by all regressors, including any fixed effects.

The nulls for F-test are: for column (1) coefficients on democratization and on multiparty elections are the same; for column (2) coefficients on democratization and on leadership change are the same.

* significant at 5 percent; ${ }^{* *}$ significant at 1 percent. 
Table 7: Different Measures of Democracy

(The Dependent Variable: Death before turning the age of one year)

\begin{tabular}{|c|c|c|c|c|c|c|c|}
\hline & (1) & $(2)$ & (3) & $(4)$ & $(5)$ & (6) & $(7)$ \\
\hline Measure of Democracy: & $\mathrm{PR}<3$ & $\mathrm{PR}<4$ & $\mathrm{PR}<5$ & POLITY2>6 & POLITY2>4 & POLITY2>0 & $\begin{array}{c}\text { EXREC }>=7 \\
\& \text { PARCOMP }>=3\end{array}$ \\
\hline Democratization in the 1990 s & $\begin{array}{l}-0.008 \\
{[0.008]}\end{array}$ & $\begin{array}{l}-0.011 \\
{[0.007]}\end{array}$ & $\begin{array}{l}-0.011^{*} \\
{[0.005]}\end{array}$ & $\begin{array}{l}-0.012 \\
{[0.009]}\end{array}$ & $\begin{array}{l}-0.011 \\
{[0.006]}\end{array}$ & $\begin{array}{c}-0.014^{* *} \\
{[0.005]}\end{array}$ & $\begin{array}{c}-0.015^{* *} \\
{[0.005]}\end{array}$ \\
\hline Collapse of Democracy in the 1990 s & $\begin{array}{l}-0.021^{* *} \\
{[0.007]}\end{array}$ & $\begin{array}{l}-0.021 \\
{[0.013]}\end{array}$ & $\begin{array}{l}-0.014 \\
{[0.011]}\end{array}$ & $\begin{array}{l}-0.025 \\
{[0.014]}\end{array}$ & $\begin{array}{l}-0.018 \\
{[0.015]}\end{array}$ & $\begin{array}{l}-0.046 \\
{[0.026]}\end{array}$ & $\begin{array}{l}-0.022 \\
{[0.014]}\end{array}$ \\
\hline F-test & 6.65 & 1.21 & 0.15 & 1.84 & 0.36 & 1.46 & 0.36 \\
\hline$p$-value & 0.016 & 0.280 & 0.701 & 0.187 & 0.551 & 0.238 & 0.554 \\
\hline Girl dummy & YES & YES & YES & YES & YES & YES & YES \\
\hline Multiple birth dummy & YES & YES & YES & YES & YES & YES & YES \\
\hline Mother fixed effects & YES & YES & YES & YES & YES & YES & YES \\
\hline Year fixed effects & YES & YES & YES & YES & YES & YES & YES \\
\hline Country-specific linear trends & YES & YES & YES & YES & YES & YES & YES \\
\hline Number of Countries & 28 & 28 & 28 & 28 & 28 & 28 & 28 \\
\hline Number of Mothers & 161521 & 161521 & 161521 & 161864 & 161864 & 161864 & 161864 \\
\hline Observations & 629573 & 629573 & 629573 & 643791 & 643791 & 643791 & 643791 \\
\hline Adjusted R-squared & 0.077 & 0.077 & 0.077 & 0.077 & 0.077 & 0.077 & 0.077 \\
\hline
\end{tabular}

Notes : Standard errors clustered at the country level are reported in brackets. In columns (1), (2), and (3), a country-year is regarded as democratic if

Freedom House's Political Rights Index is less than 3, 4, or 5, respectively; in columns (4), (5), and (6), a country-year is democratic if POLITY IV's

POLITY2 score is more than 6,4 , or 0 , respectively. In column (7), a counry-year is democratic if POLITY IV's variable EXREC is 7 or higher and if another POLITY IV variable PARCOMP is 3 or higher. Adjusted R-squared refers to variation explained by all regressors, including any fixed effects. The null for F-tests is that coefficients on democratization and the collapse of democracy are the same.

* significant at 5 percent; ** at 1 percent. 
Table 8: Summary Statistics for Pathway Analysis

\begin{tabular}{|c|c|c|c|c|}
\hline \multirow{3}{*}{ Countries: } & \multirow{3}{*}{$\begin{array}{l}(1) \\
\text { All }\end{array}$} & (2) & (3) & \multirow{3}{*}{$\begin{array}{c}(4) \\
\text { Non-democratized }\end{array}$} \\
\hline & & \multicolumn{2}{|c|}{ Democratized } & \\
\hline & & Before & After & \\
\hline \multicolumn{5}{|l|}{ Tetanus Toxoid } \\
\hline \multirow[t]{2}{*}{$(\mathrm{All})$} & 0.700 & 0.572 & 0.615 & 0.764 \\
\hline & 195564 & 34196 & 40053 & 121315 \\
\hline \multirow[t]{2}{*}{ (Educated) } & 0.812 & 0.774 & 0.754 & 0.836 \\
\hline & 98158 & 15639 & 17327 & 65192 \\
\hline \multirow[t]{2}{*}{ (Uneducated) } & 0.587 & 0.401 & 0.510 & 0.680 \\
\hline & 97384 & 18554 & 22724 & 56106 \\
\hline \multicolumn{5}{|c|}{ Delivery Assistance } \\
\hline \multirow[t]{2}{*}{ (All) } & 0.445 & 0.412 & 0.436 & 0.456 \\
\hline & 231645 & 32153 & 54428 & 145064 \\
\hline \multirow[t]{2}{*}{ (Educated) } & 0.578 & 0.621 & 0.552 & 0.577 \\
\hline & 117787 & 14682 & 23217 & 79888 \\
\hline \multirow[t]{2}{*}{ (Uneducated) } & 0.307 & 0.235 & 0.349 & 0.307 \\
\hline & 113836 & 17468 & 31209 & 65159 \\
\hline \multicolumn{5}{|l|}{ Ever Breastfed } \\
\hline \multirow[t]{2}{*}{$(\mathrm{All})$} & 0.975 & 0.976 & 0.977 & 0.975 \\
\hline & 228567 & 31551 & 53507 & 143509 \\
\hline \multirow[t]{2}{*}{ (Educated) } & 0.974 & 0.976 & 0.979 & 0.973 \\
\hline & 116584 & 14455 & 23020 & 79109 \\
\hline \multirow[t]{2}{*}{ (Uneducated) } & 0.977 & 0.977 & 0.975 & 0.977 \\
\hline & 111961 & 17093 & 30485 & 64383 \\
\hline \multicolumn{5}{|c|}{ Access to Toilets } \\
\hline \multirow[t]{2}{*}{ (All) } & 0.049 & 0.052 & 0.053 & 0.047 \\
\hline & 57111 & 6539 & 16054 & 34518 \\
\hline \multirow[t]{2}{*}{ (Educated) } & 0.082 & 0.109 & 0.095 & 0.074 \\
\hline & 29574 & 2760 & 7091 & 19723 \\
\hline \multirow[t]{2}{*}{ (Uneducated) } & 0.014 & 0.011 & 0.020 & 0.012 \\
\hline & 27532 & 3779 & 8962 & 14791 \\
\hline \multicolumn{5}{|l|}{ Radio } \\
\hline (All) & 0.552 & 0.520 & 0.573 & 0.548 \\
\hline & 57121 & 6527 & 16048 & 34546 \\
\hline (Educated) & 0.592 & 0.605 & 0.570 & 0.598 \\
\hline & 29578 & 2755 & 7090 & 19733 \\
\hline (Uneducated) & 0.509 & 0.458 & 0.575 & 0.482 \\
\hline & 27538 & 3772 & 8957 & 14809 \\
\hline Television & & & & \\
\hline (All) & 0.096 & 0.132 & 0.099 & 0.088 \\
\hline & 57121 & 6527 & 16048 & 34546 \\
\hline (Educated) & 0.142 & 0.220 & 0.151 & 0.127 \\
\hline & 29578 & 2755 & 7090 & 19733 \\
\hline (Uneducated) & 0.047 & 0.067 & 0.057 & 0.036 \\
\hline & 27538 & 3772 & 8957 & 14809 \\
\hline Frige & & & & \\
\hline (All) & 0.052 & 0.079 & 0.045 & 0.051 \\
\hline & 54084 & 5702 & 13851 & 34531 \\
\hline (Educated) & 0.088 & 0.150 & 0.091 & 0.080 \\
\hline & 27599 & 2306 & 5571 & 19722 \\
\hline (Uneducated) & 0.015 & 0.031 & 0.014 & 0.012 \\
\hline & 26480 & 3396 & 8279 & 14805 \\
\hline
\end{tabular}


Table 8 (continued): Summary Statistics for Pathway Analysis

\begin{tabular}{|c|c|c|c|c|}
\hline \multirow{3}{*}{ Countries: } & \multirow{3}{*}{$\begin{array}{l}(1) \\
\text { All }\end{array}$} & $(2)$ & (3) & \multirow{3}{*}{$\begin{array}{c}(4) \\
\text { Non-democratized }\end{array}$} \\
\hline & & \multicolumn{2}{|c|}{ Democratized } & \\
\hline & & Before & After & \\
\hline \multicolumn{5}{|l|}{ Bicycle } \\
\hline \multirow[t]{2}{*}{ (All) } & 0.355 & 0.228 & 0.388 & 0.364 \\
\hline & 57097 & 6518 & 16054 & 34525 \\
\hline \multirow[t]{2}{*}{ (Educated) } & 0.297 & 0.195 & 0.331 & 0.299 \\
\hline & 29565 & 2747 & 7093 & 19725 \\
\hline \multirow[t]{2}{*}{ (Uneducated) } & 0.417 & 0.252 & 0.432 & 0.450 \\
\hline & 27527 & 3771 & 8960 & 14796 \\
\hline \multicolumn{5}{|l|}{ Motorcycle } \\
\hline \multirow[t]{2}{*}{ (All) } & 0.086 & 0.119 & 0.117 & 0.065 \\
\hline & 55970 & 6520 & 16044 & 33406 \\
\hline \multirow[t]{2}{*}{ (Educated) } & 0.065 & 0.126 & 0.082 & 0.049 \\
\hline & 28637 & 2747 & 7086 & 18804 \\
\hline \multirow[t]{2}{*}{ (Uneducated) } & 0.109 & 0.114 & 0.145 & 0.086 \\
\hline & 27328 & 3773 & 8957 & 14598 \\
\hline \multicolumn{5}{|l|}{ Car } \\
\hline \multirow[t]{2}{*}{ (All) } & 0.035 & 0.052 & 0.030 & 0.034 \\
\hline & 55037 & 6518 & 16032 & 32487 \\
\hline \multirow[t]{2}{*}{ (Educated) } & 0.052 & 0.080 & 0.045 & 0.051 \\
\hline & 28061 & 2745 & 7084 & 18232 \\
\hline \multirow[t]{2}{*}{ (Uneducated) } & 0.016 & 0.032 & 0.018 & 0.012 \\
\hline & 26971 & 3773 & 8947 & 14251 \\
\hline \multicolumn{5}{|l|}{ Electricity } \\
\hline \multirow[t]{2}{*}{ (All) } & 0.137 & 0.208 & 0.116 & 0.134 \\
\hline & 56081 & 6531 & 16031 & 33519 \\
\hline \multirow[t]{2}{*}{ (Educated) } & 0.206 & 0.339 & 0.186 & 0.195 \\
\hline & 29018 & 2759 & 7086 & 19173 \\
\hline \multirow[t]{2}{*}{ (Uneducated) } & 0.063 & 0.112 & 0.062 & 0.052 \\
\hline & 27058 & 3772 & 8944 & 14342 \\
\hline
\end{tabular}

Notes: In each cell, the sample mean is reported at the top row; the number of observations at the bottom row. Column (2) reports means for children born in democratized countries until the year of democratization; Column (3) for children born in democratized countries after the year of democratization; Column (4) for children born in non-democratized countries. 
Table 9: Maternal Health Care

\begin{tabular}{|c|c|c|c|c|c|c|}
\hline & (1) & (2) & (3) & (4) & (5) & (6) \\
\hline Dependent Variable: & $\begin{array}{l}\text { Neonatal } \\
\text { Death }\end{array}$ & $\begin{array}{l}\text { Neonatal } \\
\text { Death }\end{array}$ & $\begin{array}{c}\text { Tetanus } \\
\text { Toxoid }\end{array}$ & $\begin{array}{c}\text { Tetanus } \\
\text { Toxoid }\end{array}$ & $\begin{array}{l}\text { Delivery } \\
\text { Assistance }\end{array}$ & $\begin{array}{l}\text { Delivery } \\
\text { Assistance }\end{array}$ \\
\hline Democratization & $\begin{array}{c}-0.010^{* *} \\
{[0.003]}\end{array}$ & & $\begin{array}{c}0.041 \\
{[0.049]}\end{array}$ & & $\begin{array}{c}0.049 \\
{[0.032]}\end{array}$ & \\
\hline $\begin{array}{l}\text { Democratization } \\
\text { interacted with Educated }\end{array}$ & & $\begin{array}{c}-0.007+ \\
{[0.004]}\end{array}$ & & $\begin{array}{l}-0.024 \\
{[0.036]}\end{array}$ & & $\begin{array}{c}0.021 \\
{[0.026]}\end{array}$ \\
\hline $\begin{array}{l}\text { Democratization } \\
\text { interacted with Uneducated }\end{array}$ & & $\begin{array}{l}-0.012^{* *} \\
{[0.003]}\end{array}$ & & $\begin{array}{l}0.100+ \\
{[0.048]}\end{array}$ & & $\begin{array}{l}0.076^{*} \\
{[0.034]}\end{array}$ \\
\hline Multiple birth & $\begin{array}{l}0.164^{* *} \\
{[0.009]}\end{array}$ & $\begin{array}{l}0.164^{* *} \\
{[0.009]}\end{array}$ & & & $\begin{array}{l}0.071^{* *} \\
{[0.007]}\end{array}$ & $\begin{array}{l}0.071^{* *} \\
{[0.007]}\end{array}$ \\
\hline F-test & & 8.65 & & 17.31 & & 6.20 \\
\hline $\mathrm{p}$-value & & 0.009 & & 0.001 & & 0.023 \\
\hline Girl dummy & YES & YES & $\mathrm{NO}$ & $\mathrm{NO}$ & NO & $\mathrm{NO}$ \\
\hline Mother fixed effects & YES & YES & N/A & N/A & N/A & N/A \\
\hline Mother category fixed effects & N/A & N/A & YES & YES & YES & YES \\
\hline Year fixed effects & YES & YES & YES & YES & YES & YES \\
\hline Country-specific linear trends & YES & YES & NO & NO & NO & NO \\
\hline Number of Countries & 19 & 19 & 18 & 18 & 19 & 19 \\
\hline Number of Mothers & 118010 & 118007 & $N / A$ & $\mathrm{~N} / \mathrm{A}$ & N/A & N/A \\
\hline Number of Mother categories & N/A & N/A & 23255 & 23240 & 23786 & 23771 \\
\hline Observations & 475995 & 475986 & 195564 & 195542 & 231645 & 231623 \\
\hline Adjusted R-squared & 0.081 & 0.081 & 0.237 & 0.238 & 0.396 & 0.396 \\
\hline
\end{tabular}

Notes: Robust standard errors clusterd at the country level are reported in brackets. Neonatal death is death before turning the age of 1 month. Adjusted R-squared refers to variation explained by all the regressors, including any fixed effects. The null for F-tests is that coefficients on the two interaction terms between democratization and mothers' education level are the same.

+ significant at $10 \%$; ${ }^{*}$ significant at $5 \%$; ${ }^{* *}$ significant at $1 \%$. 
Table 10: Breastfeeding and Sanitation

\begin{tabular}{|c|c|c|c|c|c|c|}
\hline & (1) & $(2)$ & (3) & $(4)$ & $(5)$ & (6) \\
\hline Dependent Variable: & $\begin{array}{l}\text { Infant } \\
\text { Death }\end{array}$ & $\begin{array}{l}\text { Infant } \\
\text { Death }\end{array}$ & $\begin{array}{c}\text { Ever } \\
\text { Breastfed }\end{array}$ & $\begin{array}{c}\text { Ever } \\
\text { Breastfed }\end{array}$ & $\begin{array}{l}\text { Access to } \\
\text { Toilets }\end{array}$ & $\begin{array}{l}\text { Access to } \\
\text { Toilets }\end{array}$ \\
\hline Democratization & $\begin{array}{l}-0.020^{*} \\
{[0.007]}\end{array}$ & & $\begin{array}{l}0.011^{*} \\
{[0.004]}\end{array}$ & & $\begin{array}{l}0.016^{*} \\
{[0.007]}\end{array}$ & \\
\hline $\begin{array}{l}\text { Democratization } \\
\text { interacted with Educated }\end{array}$ & & $\begin{array}{l}-0.012 \\
{[0.008]}\end{array}$ & & $\begin{array}{c}0.009 \\
{[0.006]}\end{array}$ & & $\begin{array}{c}0.022 \\
{[0.015]}\end{array}$ \\
\hline $\begin{array}{l}\text { Democratization } \\
\text { interacted with Uneducated }\end{array}$ & & $\begin{array}{l}-0.025^{*} \\
{[0.009]}\end{array}$ & & $\begin{array}{l}0.012^{*} \\
{[0.005]}\end{array}$ & & $\begin{array}{l}0.013^{*} \\
{[0.005]}\end{array}$ \\
\hline Girl & $\begin{array}{c}-0.014^{* *} \\
{[0.002]}\end{array}$ & $\begin{array}{c}-0.014^{* *} \\
{[0.002]}\end{array}$ & $\begin{array}{l}0.005^{* *} \\
{[0.001]}\end{array}$ & $\begin{array}{l}0.004^{* *} \\
{[0.001]}\end{array}$ & & \\
\hline Born in a multiple birth & $\begin{array}{l}0.229^{* *} \\
{[0.013]}\end{array}$ & $\begin{array}{l}0.229^{* *} \\
{[0.013]}\end{array}$ & $\begin{array}{l}-0.067^{* *} \\
{[0.006]}\end{array}$ & $\begin{array}{l}-0.067^{* *} \\
{[0.006]}\end{array}$ & & \\
\hline F-test & & 5.90 & & 0.08 & & 0.42 \\
\hline $\mathrm{p}$-value & & 0.026 & & 0.776 & & 0.519 \\
\hline Mother fixed effects & YES & YES & N/A & N/A & N/A & N/A \\
\hline fixed effects & N/A & N/A & YES & YES & YES & YES \\
\hline Year fixed effects & YES & YES & YES & YES & NO & NO \\
\hline riod fixed eff & NO & NO & NO & NO & YES & YES \\
\hline Country-specific linear trends & YES & YES & NO & NO & NO & NO \\
\hline Number of Clusters & 19 & 19 & 19 & 19 & 50 & 50 \\
\hline Number of Mothers & 118010 & 118007 & N/A & N/A & N/A & N/A \\
\hline Number of Mother categories & $\mathrm{N} / \mathrm{A}$ & N/A & 23730 & 23715 & 16212 & 16207 \\
\hline Observations & 475995 & 475986 & 228567 & 228545 & 57111 & 57106 \\
\hline Adjusted R-sqaured & 0.077 & 0.077 & 0.035 & 0.035 & 0.402 & 0.402 \\
\hline
\end{tabular}

Notes: Robust standard errors clusterd at the country level (columns (1) to (4)) or at the country-year level (columns (5) and (6)) are reported in brackets. Infant death is death before turning the age of 1 year. The number of clusters refers to the number of countries in columns (1) to (4) and to the number of country-year cells in columns (5) and (6). Adjusted R-squared refers to variation explained by all the regressors, including any fixed effects. The null for F-tests is that coefficients on the two interaction terms between democratization and mothers' education level are the same.

+ significant at $10 \% ;{ }^{*}$ significant at $5 \% ;{ }^{* *}$ significant at $1 \%$ 
Table 11: Impact of Democratization on Asset Ownership and Access to Electricity

\begin{tabular}{lccccccc}
\hline & $(1)$ & $(2)$ & $(3)$ & $(4)$ & $(5)$ & $(6)$ & $(7)$ \\
Dependent variable: & Radio & Television & Refrigerator & Bicycle & Motorcycle & Car & Electricity \\
\hline Panel A & & & & & & & \\
Democratization & -0.027 & -0.019 & 0.002 & -0.010 & -0.006 & 0.001 & 0.004 \\
& {$[0.022]$} & {$[0.014]$} & {$[0.009]$} & {$[0.030]$} & {$[0.008]$} & {$[0.005]$} & {$[0.018]$} \\
\hline Mother-category fixed effects & YES & YES & YES & YES & YES & YES & YES \\
5-year period fixed effects & YES & YES & YES & YES & YES & YES & YES \\
Number of clusters & 50 & 50 & 48 & 50 & 49 & 48 & 48 \\
Number of mother categories & 16214 & 16214 & 14933 & 16206 & 16185 & 15866 & 15903 \\
Observations & 57121 & 57121 & 54084 & 57097 & 55970 & 55037 & 56081 \\
Adjusted R-squared & 0.148 & 0.352 & 0.313 & 0.292 & 0.193 & 0.156 & 0.520 \\
\hline Panel B & & & & & & & \\
Democratization interacted with & & & & & & & 0.006 \\
Educated & -0.031 & 0.005 & 0.030 & -0.004 & 0.001 & 0.008 & 0.006 \\
& {$[0.025]$} & {$[0.024]$} & {$[0.029]$} & {$[0.033]$} & {$[0.011]$} & {$[0.010]$} & {$[0.023]$} \\
Uneducated & -0.025 & $-0.033^{* *}$ & $-0.013^{*}$ & -0.0130 & -0.010 & -0.004 & 0.003 \\
& {$[0.023]$} & {$[0.012]$} & {$[0.006]$} & {$[0.034]$} & {$[0.010]$} & {$[0.004]$} & {$[0.019]$} \\
F-test & 0.08 & 3.31 & 2.08 & 0.09 & 0.50 & 1.96 & 0.02 \\
p-value & 0.773 & 0.075 & 0.156 & 0.771 & 0.482 & 0.168 & 0.887 \\
\hline Mother-category fixed effects & YES & YES & YES & YES & YES & YES & YES \\
5-year period fixed effects & YES & YES & YES & YES & YES & YES & YES \\
Number of clusters & 50 & 50 & 48 & 50 & 49 & 48 & 48 \\
Number of mother categories & 16209 & 16209 & 14928 & 16201 & 16180 & 15861 & 15898 \\
Observations & 57116 & 57116 & 54079 & 57092 & 55965 & 55032 & 56076 \\
Adjusted R-squared & 0.148 & 0.353 & 0.313 & 0.292 & 0.193 & 0.157 & 0.520 \\
\hline
\end{tabular}

Notes: Reported in brackets are standard errors clustered at the country-year level. Panels A and B correspond to different regressions for each column. Mothers are categorised by administrative regions of residence, urban/rural areas of residence, education level, and age cohort to control for mother-category fixed effects. 5-year period fixed effects are those for 1985-89, 1990-94, 1995-99, and 2000-04. The number of clusters refers to the number of country-year cells. Adjusted R-squared refers to variation explained by all regressors, including any fixed effects. The null for F-test in Panel B is that coefficients on the two interaction terms between democratization and mothers' education level are the same.

+ significant at $10 \% ;{ }^{*}$ significant at $5 \% ;{ }^{* *}$ significant at $1 \%$ 


\begin{tabular}{|c|c|c|c|c|}
\hline Group of countries: & $\begin{array}{c}(1) \\
\text { Democratized }\end{array}$ & $\begin{array}{c}(2) \\
\text { Non-democratized }\end{array}$ & $\begin{array}{c}(3) \\
\text { Sample }\end{array}$ & $\begin{array}{l}(4) \\
\text { All }\end{array}$ \\
\hline Per Capita Income in 1990 & 1657 & 2020 & 1877 & 2182 \\
\hline \multirow[t]{2}{*}{ (1996 constant int'I dollars) } & (2078) & '(2036) & (2022) & $(2353)$ \\
\hline & 11 & 17 & 28 & 42 \\
\hline Average Years of Schooling & $\begin{array}{c}2.81 \\
(179)\end{array}$ & 2.92 & 2.87 & 2.93 \\
\hline (for those aged 15 or over) & 7 & 11 & 18 & 30 \\
\hline Average Years of Schooling & 2.42 & 2.19 & 2.28 & 2.37 \\
\hline in 1990 & (1.92) & '(.94) & $(1.36)$ & (1.61) \\
\hline (for female aged 15 or over) & 7 & 11 & 18 & 30 \\
\hline \multirow{3}{*}{$\begin{array}{l}\text { Ethnic Fractionalization Index } \\
\text { (0 to } 1)\end{array}$} & 0.640 & 0.709 & 0.682 & 0.659 \\
\hline & $(0.269)$ & '(0.159) & $(0.207)$ & $(0.233)$ \\
\hline & 11 & 17 & 28 & 46 \\
\hline \multirow{3}{*}{$\begin{array}{l}\text { British Legal Origin } \\
\text { (dummy variable) }\end{array}$} & 0.455 & 0.353 & 0.393 & 0.383 \\
\hline & $(0.522)$ & '(0.493) & $(0.497)$ & $(0.491)$ \\
\hline & 11 & 17 & 28 & 47 \\
\hline \multirow{3}{*}{$\begin{array}{l}\text { European Settler Mortality } \\
\text { (per } 1000 \text { mean strengths) }\end{array}$} & 987 & 369 & 587 & 556 \\
\hline & (1205) & '(213) & (758) & (693) \\
\hline & 6 & 11 & 17 & 23 \\
\hline \multirow{2}{*}{$\begin{array}{l}\text { Malaria Ecology Index } \\
(0 \text { to more than } 30)\end{array}$} & 10.53 & 12.96 & 12.00 & 11.38 \\
\hline & $\begin{array}{c}(10.31) \\
11\end{array}$ & $\begin{array}{c}\text { '(8.67) } \\
17\end{array}$ & $\begin{array}{l}(9.24) \\
28\end{array}$ & $\begin{array}{l}(7.98) \\
46\end{array}$ \\
\hline \multirow{3}{*}{$\begin{array}{l}\text { HIV infection rate in } 2001 \\
\text { (\% of adults aged } 15-49)\end{array}$} & 9.71 & 7.45 & 8.29 & 9.05 \\
\hline & $(10.06)$ & '(6.58) & $(7.93)$ & $\begin{array}{c}(9.86) \\
38\end{array}$ \\
\hline & 10 & 17 & 27 & 38 \\
\hline$\%$ of years of armed conflicts & 14.68 & 16.54 & 15.81 & 21.52 \\
\hline from 1951 or independence & $(23.30)$ & '(24.85) & $(23.83)$ & (29.65) \\
\hline to 2004 & 11 & 17 & 28 & 47 \\
\hline
\end{tabular}

Sources: Penn World Table 6.1 for per capita income; Barro and Lee (2000) for years of schooling; Alesina et al. (2003) for ethnic fractionalization; La Porta et al. (1999) for British legal origin; Acemoglu et al. (2001) for European settler mortality; Kiszewski et al. (2004) for malaria ecology; the World Development Report 2005 for the HIV infection rate; and Armed Conflict Dataset Version 3-2005b (Gleditsch et al. 2002) for armed conflicts.

Notes: In each cell, the mean, the standard deviation (in parentheses), and the number of countries are reported at the top, the middle, and the bottom row, respectively. Column (1) includes 11 democratized countries; colulmn (2) 17 non-democratized countries; column (3) 28 countries with the DHS surveys available; column (4) all the countries in Sub-Saharan Africa (excluding Eritrea). Eritrea is excluded because it became independent in 1993, and data in 1990 is therefore not available. 
Appendix Table A2: Years of DHS surveys used in the analysis

\begin{tabular}{|c|c|c|}
\hline Country & Infant Mortality Analysis & Pathway Analysis \\
\hline Benin & 2001 & 2001,1996 \\
\hline Burkina Faso & 2003 & 2003, 1998, 1992 \\
\hline Cameroon & 2004 & 2004, 1998, 1991 \\
\hline Chad & 2004 & \\
\hline Comoros & 1996 & \\
\hline Cote d'Ivoire & 1998 & \\
\hline Ethiopia & 2000 & \\
\hline Gabon & 2000 & \\
\hline Ghana & 2003 & 2003, 1998, 1993, 1988 \\
\hline Guinea & 1999 & \\
\hline Kenya & 2003 & 2003, 1998, 1993, 1989 \\
\hline Lesotho & 2004 & \\
\hline Madagascar & 1997 & 1997, 1992 \\
\hline Malawi & 2000 & 2000, 1992 \\
\hline Mali & 2001 & 2001, 1995, 1987 \\
\hline Mauritania & 2000 & \\
\hline Mozambique & 2003 & 2003, 1997 \\
\hline Namibia & 2000 & $2000^{*}, 1992^{*}$ \\
\hline Niger & 1998 & 1998, 1992 \\
\hline Nigeria & 2003 & 2003, 1999, 1990 \\
\hline Rwanda & 2000 & 2000, 1992 \\
\hline Senegal & 1997 & 1997, 1992 \\
\hline South Africa & 1998 & \\
\hline Tanzania & 2004 & 2004, 1999, 1996, 1992 \\
\hline Togo & 1998 & 1998, 1988 \\
\hline Uganda & 2000 & 2000, 1995, 1988 \\
\hline Zambia & 2001 & 2001, 1996, 1992 \\
\hline Zimbabwe & 1999 & 1999, 1988 \\
\hline
\end{tabular}

Notes: If a survey was completed in the following year, the year in the table refers to the one in which the survey began.

* Namibia surveys are not used for analysis of tetanus toxoid injections because the 2000 survey does not collect information on it, leaving only one round of survey available. 
Appendix Table A3: Dynamics of Infant Mortality Before and After Democratization (The Dependent Variable: Death before turning the age of one year)

\begin{tabular}{lc}
\hline 5 Years Before & -0.004 \\
& {$[0.006]$} \\
4 Years Before & -0.001 \\
& {$[0.005]$} \\
3 Years Before & -0.004 \\
& {$[0.004]$} \\
2 Years Before & -0.009 \\
& {$[0.008]$} \\
1 Year Before & -0.008 \\
& {$[0.008]$} \\
Year of Democratization & -0.014 \\
& {$[0.011]$} \\
1 Year After & $-0.023^{*}$ \\
& {$[0.010]$} \\
2 Years After & $-0.028^{*}$ \\
& {$[0.012]$} \\
3 Years After & -0.030 \\
& {$[0.016]$} \\
4 Years or More After & $-0.038^{* *}$ \\
& {$[0.013]$} \\
F-test & 0.44 \\
& 0.817 \\
\hline Controls: & YES \\
Sex of Baby & YES \\
Multiple Birth & YES \\
Mother fixed effects & YES \\
Year fixed effects & YES \\
Country-specific linear trends & 28 \\
\hline Number of Countries & 161876 \\
Number of Mothers & 643846 \\
Observations & 0.077 \\
Adjusted R-squared & \\
\hline Notes: Robust standard errors clustered at the \\
country level are reported in brackets. The null for \\
F-test is that five coefficients on dummies for years \\
before democratization are all zero. Adjusted R- \\
squared refers to variation explained by all \\
regressors, including any fixed effects. \\
* significant at 5\%; ** significant at $1 \%$ \\
\end{tabular}

